Aquatic Nuisance Species Research Program

Incidence and Management Costs of Freshwater Aquatic Nuisance Species at Projects Operated by the U.S. Army Corps of Engineers

Richard A. Cole, Paul F. Scodari, and Monica A. Franklin

July 2010 


\section{Incidence and Management Costs of Freshwater Aquatic Nuisance Species at Projects Operated by the U.S. Army Corps of Engineers}

Richard A. Cole, Paul F. Scodari, and Monica Franklin

Institute for Water Resources

U.S. Army Corps of Engineers

7701 Telegraph Road, Casey Building

Alexandria, VA 22315-3868

Final report

Approved for public release; distribution is unlimited

Prepared for Headquarters, U.S. Army Corps of Engineers

Washington, DC 20314-1000

Monitored by U.S. Army Engineer Research and Development Center 3909 Halls Ferry Road, Vicksburg, MS 39180-6199 


\begin{abstract}
This study investigates the costs and possible benefits associated with freshwater aquatic nuisance species (ANS) at projects operated by the U.S. Army Corps of Engineers. Based on results from a random-sample survey of three Corps Divisions (LRD, NWD, and SAD), ANS occurred at $16.9 \%$ of Corps projects and ANS management costs were incurred at 10.5\% of the projects $(\$ 4,165,500$ total expense). Most ANS occurrences were large aquatic plants, which incurred $98 \%$ of the management cost. Algae management made up most of the remaining cost. Based on a literature review, Corps expenses are a small fraction of the total ANS management expense in the United States. Florida management costs are among the best documented and are over 40 times the Corps expenditure in Florida. Corps costs per unit effort are lower than average. If the benefit-to-cost ratio found for Florida in the ANS literature generally applies, the benefits derived from Corps ANS management are about \$35 million per year in the J acksonville District alone and $\$ 50$ million per year in the surveyed Divisions. Benefits from improved habitat for threatened native species may also be substantial, but are poorly estimated.
\end{abstract}

DISCLAIMER: The contents of this report are not to be used for advertising, publication, or promotional purposes. Citation of trade names does not constitute an official endorsement or approval of the use of such commercial products. All product names and trademarks cited are the property of their respective owners. The findings of this report are not to be construed as an official Department of the Army position unless so designated by other authorized documents. 


\section{Contents}

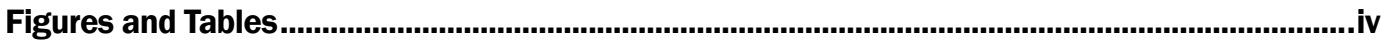

Preface

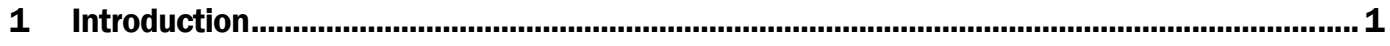

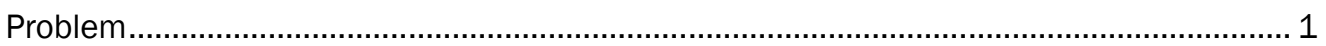

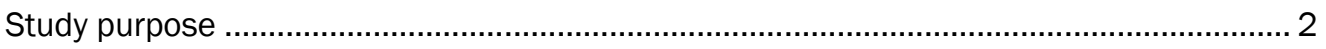

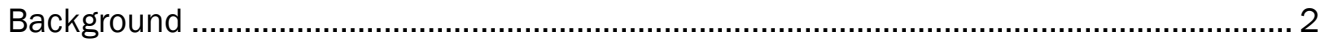

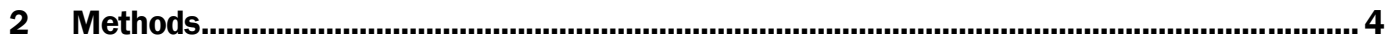

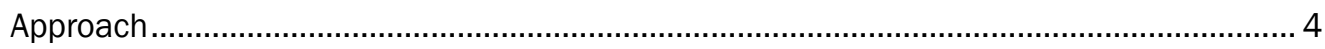

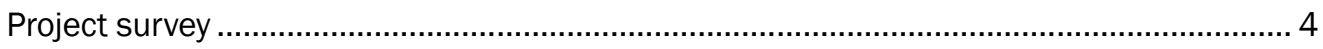

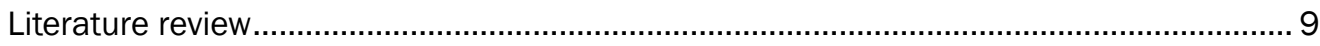

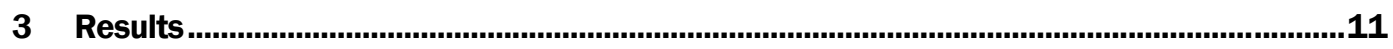

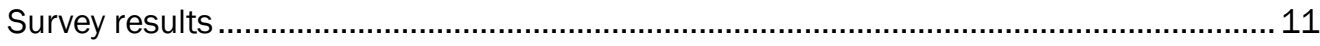

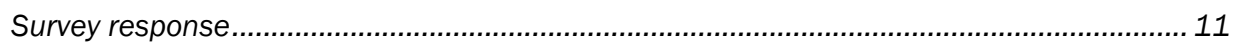

ANS occurrence at Corps projects ........................................................................... 11

Service impacts at Corps projects................................................................................ 16

Management actions and expenditures ...................................................................... 18

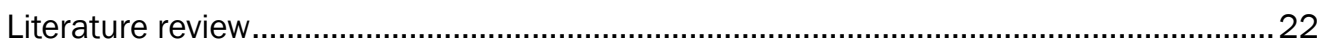

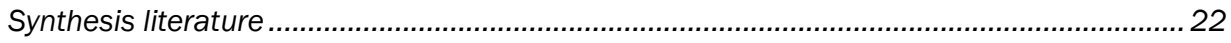

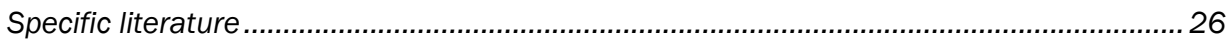

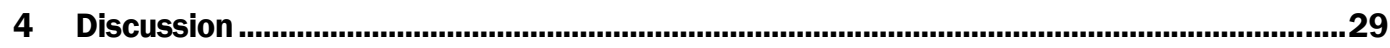

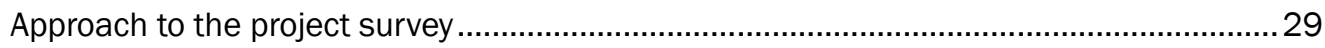

Extent of ANS impacts at Corps projects ..................................................................... 31

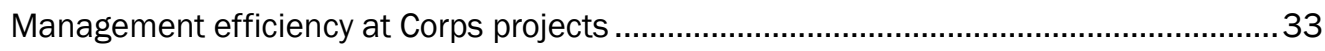

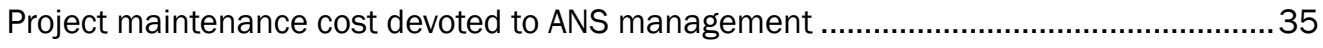

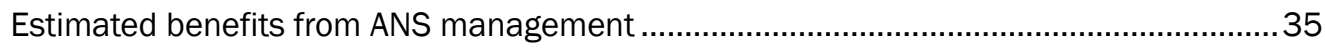

Further study/monitoring........................................................................................ 36

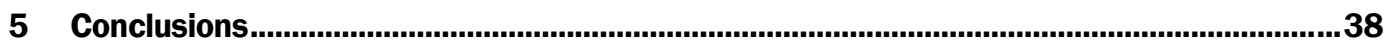

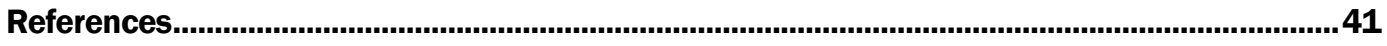

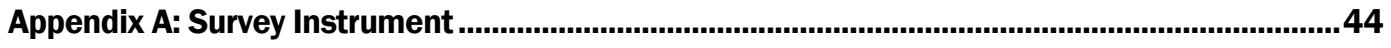

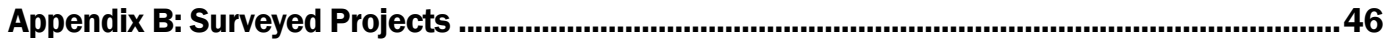

\section{Report Documentation Page}




\section{Figures and Tables}

\section{Figure}

Figure 1. General approach used to estimate costs and benefits from management of aquatic nuisance species at Corps projects.

\section{Tables}

Table 1. Number of projects and response percent for all freshwater projects within project types and Corps Divisions.

Table 2. Number of times each ANS category was identified as being recently present at Civil Works projects by project category.

Table 3. ANS identified at project sites (whether or not operations funds were spent). Usually, only common names were reported and no attempt was made to verify the accuracy of the reports.

Table 4. Number of projects and percent of projects at which services were reported impacted in the three Corps Divisions sampled

Table 5. Reported ANS management costs (\$) by ANS category and project type for $\mathrm{FY} 2004$

Table 6. Reported operations expenditures (\$) for managing ANS impacts in 2004 and budgeted for 2005 by ANS category and project type summed for all three Divisions studied (LRD, NWD, and SAD).

Table 7. Estimated total ANS management cost (\$) for FY 2004 by District and project type in the SAD, NWD, and LRD. 


\section{Preface}

During this study, Richard Cole, Paul Scodari, and Monica A. Franklin were, respectively, senior environmental planner, senior economist, and research technician at the Institute for Water Resources (Robert Pietrowsky, Director), U. S. Army Corps of Engineers. The authors are especially indebted to the many District and Division employees who responded to the survey that was the source of much of the research results reported here. For their report review comments and editorial suggestions, we thank Dwilette G. McFarland and Richard F. Lance at the U.S. Army Engineer Research and Development Center (ERDC).

This report is published as a product of the Aquatic Nuisance Species Research Program (ANSRP), ERDC, Vicksburg, MS. At the time of publication, Dr. Linda S. Nelson served as ANSRP Program Manager.

COL Gary E. J ohnston was Commander and Executive Director of ERDC. Dr. J effery P. Holland was ERDC Director. 


\section{Introduction}

\section{Problem}

Aquatic nuisance species (ANS) are widely believed to be a growing problem for water resource management in the United States and elsewhere. ANS are defined in this report as those aquatic plants, animals, and microbes that impose greater economic and environmental costs than the economic and environmental benefits they provide. Billions of dollars are reportedly spent annually on aquatic and terrestrial nuisance species nationwide, of which hundreds of millions are spent on ANS impact management (Office of Technology Assessment (OTA) 1993; Pimentel et al. 2000). Estimates of management costs are approximate, but are more completely assessed than estimates of the net economic and environmental benefits that accrue from ANS impact management (Lovell and Stone 2005). In recent years, the U.S. Army Corps of Engineers (Corps) has spent at least $\$ 5$ million annually on management of nuisance aquatic plants alone (U.S. Department of the Army 2004), but the total annual cost of and benefits from Corps control of all ANS are unknown.

ANS management actions and expenditures at projects operated by the Corps are determined at the Corps District level. Some of those expenditures are defrayed by Aquatic Plant Control Research Program funds appropriated as project spending in each of the Districts establishing a need (under Public Laws 85-500 and 99-662). Such expenditures are stated in Civil Works Annual Reports and recently amount to about $\$ 5$ million per year (U.S. Department of the Army 2004). Other ANS management costs are less readily identified, being incorporated into categories of project operations and maintenance that do not explicitly reveal their involvement. Real or anticipated ANS management problems have been substantial enough, however, to justify Corps investment in research and development, especially for nuisance aquatic plants, freshwater clams, and certain invasive fish species. Even so, aggregate costs and anticipated benefits of ANS management have yet to be comprehensively assessed at program levels. Program management seeks this information to facilitate budget allocation decisions in an increasingly competitive environment for operations funding. 


\section{Study purpose}

The purpose of this study was to investigate the potential dimensions of freshwater ANS-related problems and management in reservoir, river, and Great Lakes coastal projects operated by the Corps under its Civil Works Program. The results are intended to provide information that can serve as the basis for evaluating the potential need for a more comprehensive assessment of ANS problems and management at Corps projects, and for evaluating the potential environmental and economic benefits of ANS control.

The study approach involved two main elements. First, a survey of Corpsoperated projects for ANS occurrence, ANS impacts on project environmental and economic services, and ANS management expenditures was initiated. Second, a comprehensive review of the published literature on ANS was conducted. This was used to provide a national context for examining potential ANS economic and environmental impacts at Corpsoperated projects, including potential management costs and benefits that might be gained from ANS management based on the results in the published literature.

\section{Background}

Cole (2005) provides a digest of background information that is especially relevant to this study. Numerous other published studies and reviews have shown that aquatic species can and do have adverse impacts on both environmental services (e.g., the services provided by endangered species and their supporting ecosystems) and economic services (e.g., recreation) associated with Civil Works projects and other fresh waters. ANS impacts generally take the form of altered chemical, physical, and biological attributes of project structure and waters, which can reduce project maintenance and operations effectiveness. These impacts can degrade the quality of project services and reduce project benefits, and may require management investments to sustain the quantity and quality of project services.

Many freshwater species have become troublesome under certain conditions, but only a few are repeatedly identified as "nuisance" species. Certain blue-green algae, water hyacinths, hydrilla, common reed, sea lamprey, and the zebra mussel are especially notorious for their costly impacts on freshwater services, either in a natural state or in an enhanced 
state at Civil Works projects. Others, such as mosquitoes and other biting insects, are taken more for granted and are routinely controlled by branches of agencies dedicated to that purpose. Some ANS are human pathogens, and are now routinely treated in drinking water treatment plants and monitored in waters used for contact recreation. Many, but not all, of the most costly ANS are not native to the United States.

Troublesome blue-green algae, for example, are nearly ubiquitous in favorable habitats, and introductions of some of our most valued native sport fish outside their original range are primary agents of native species decline and extinction.

The rate of non-native species invasion has increased over the past century, raising the specter of much higher environmental impacts, economic impacts, and management costs. The real and potential problems associated with invasive species have become so predominant among the impacts of nuisance species that the two are often equated. The level of ANS impacts and rates of increase in damage and management costs have not been uniform across the United States; impact hot spots occur where costs are substantially greater. Understanding of ANS dynamics is incomplete, however, and even the distributions of ANS impacts are not well documented for many freshwaters, including those influenced by Corps activities. Initial estimates of ANS costs suggest the need for more complete inventories. 


\section{Methods}

\section{Approach}

Figure 1 illustrates the specific types of information sought from the Corps project survey and the ANS literature review, and how that information was used for this study. It depicts the analytical components and linkages that would need to be quantified in order to assess:

- Baseline ANS impacts-the economic and environmental impacts of ANS problems at Corps projects

- ANS management outcomes-the reduction in ANS-caused economic and environmental impacts and net economic return from Corps ANS management.

Clearly, developing and implementing an analytical framework and methods for these assessments would be a major undertaking, one that is well beyond the scope of this study. Instead, this study used the Corps project survey and literature review to identify information on analytical components of Figure 1 that help shed light on the potential dimensions of ANS problems and management at Corps projects.

The survey of Corps projects focused on gathering information on ANS occurrence, ANS impacts on project resources, ANS impacts on project services, and ANS-specific management actions and expenditures. The ANS literature review was used to identify readily available information on ANS problems, management, and management outcomes generally. That is, the literature review was used to develop information on as many of the Figure 1 analytical components as possible, using published economic and environmental analyses of ANS problems, management actions, and management outcomes.

\section{Project survey}

A survey of Corps Districts was conducted via e-mail to determine the types of ANS occurrences, their impacts on project resources, impacts on environmental and economic services, and ANS management costs at Corps-operated projects. Rather than attempting to capture all project impacts within all Districts, it was decided to start small by sampling with 


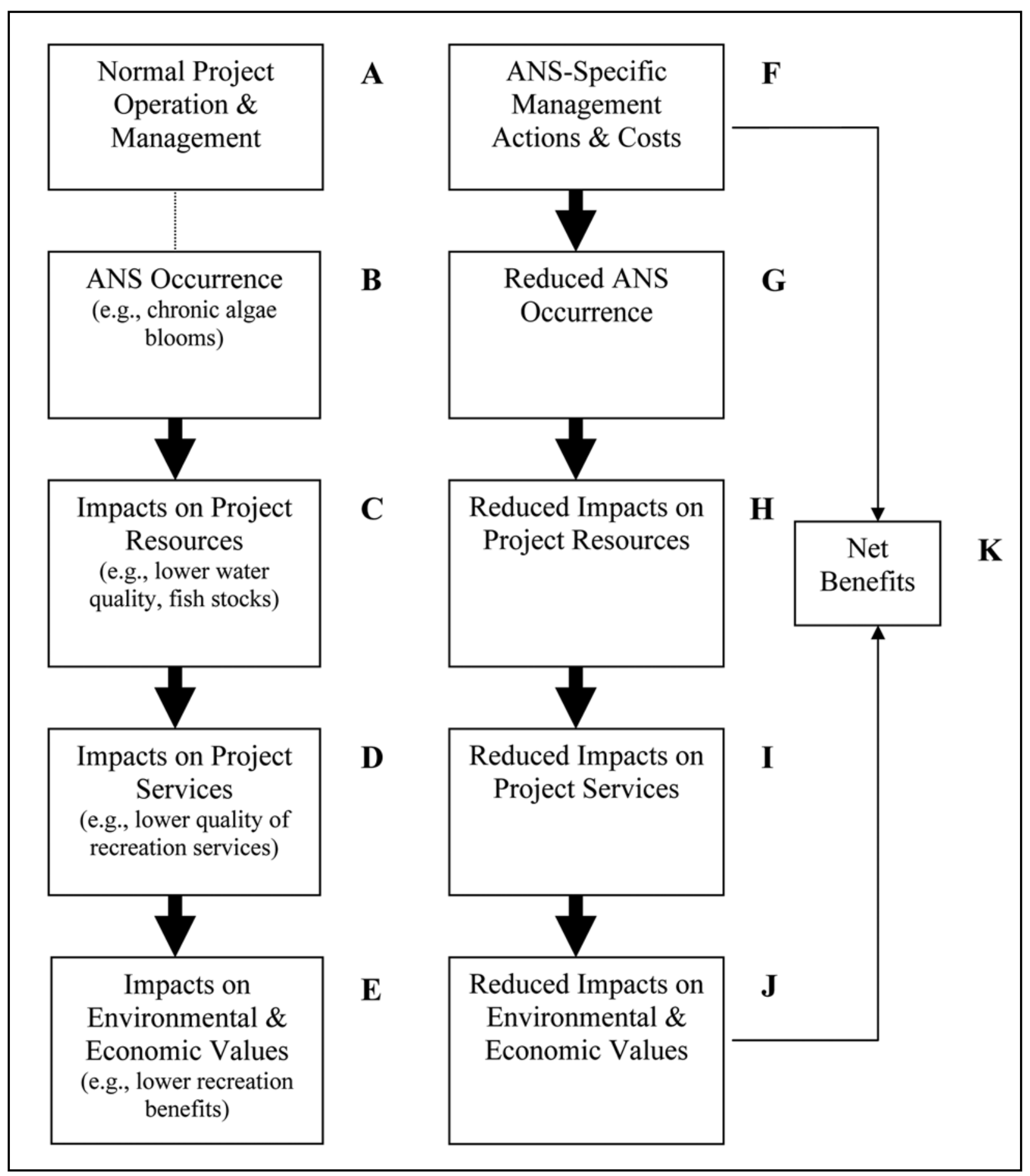

Figure 1. General approach used to estimate costs and benefits from management of aquatic nuisance species at Corps projects. 
the option of incrementally adding to the size of the survey as deemed necessary. High importance was placed on minimizing the time and personnel needed to provide the requested information, while still obtaining reasonable estimates of ANS occurrences, impacts, and management costs incurred within districts.

Three of eight Corps divisions - the Northwestern Division (NAD), South Atlantic Division (SAD), and Great Lakes and Ohio River Division (LRD) were selected for the survey because they included the full range of freshwater project types that might be impacted, including harbors, and also had well-documented ANS problems. Sampling of the five remaining Divisions was left for a subsequent survey, should it be determined that additional data might be useful.

To be included in the sampled population, the projects had to have potential for nuisance-level impacts by freshwater aquatic organisms including aquatic algae, large aquatic plants, fish, mussels and clams, water fleas and crayfish, and biting insects. All projects located in estuaries and oceans were excluded from the sampled population of projects. All flood-control levee and river channeling projects were also excluded after a preliminary assessment indicated that no impact from any of the freshwater aquatic organisms would be expected. All projects in a planning or construction phase were excluded from the sampled population of projects. The remaining Corps-operated projects fell into three project types: 1) flood control reservoirs, 2) locks and dams and dredged waterways, and 3) freshwater harbors. A total of 368 Corps-operated projects qualified for inclusion in the sampled population of projects.

The survey form (Appendix A) included a brief statement of purpose and identified the specific project for which the survey was to be filled out. Requested data included the occurrence of ANS impacts (Yes or No) from freshwater algae, large aquatic plants, fish, zebra mussels, Asiatic clams, water fleas, crayfish, biting insects, or any other freshwater species or groups. If all answers were no, the respondent was directed to stop at that point and to return the survey or to simply e-mail back that there were no ANS impacts.

If respondents identified ANS impacts, they were directed to identify the specific nature of the impact, the ANS involved, how the impact was managed in 2004, whether operations funds were spent on management, 
what the operations expense was in 2004, and what the requested management budget was for 2005. Common names of ANS were usually reported. No attempt was made to verify the identification of taxonomic groups (because assignment of scientific names implies verified identification, they are not given except when reported). Another question asked for an estimate of total District expenditures on ANS management.

The survey was administered in increments starting with a random sample of 80 projects (a $21.7 \%$ sample) from the list of 368 qualifying projects. Initially, 78 samples were randomly selected from all qualifying projects using a table of random numbers. Samples were then added from the Charleston and Wilmington Districts (one each). These Districts were not included in the first random sample selection, because they had so few qualifying projects. Results at locks and dams in the same river set were expected to be similar; therefore, only two samples were selected from the same river set within a District, except for the Ohio River, which was limited to three because of its exceptional size. For those Districts that did not separate construction projects from operations projects, only those projects that were identified as operational on the J une 1999 map of Civil Works activities were included in the sample.

Upon receipt of responses for the first survey set, the need for additional samples was evaluated. It was determined that no further sampling of Great Lakes harbor sites was needed, based on a $23.9 \%$ sampling intensity and a consistent report of no ANS management expenses at each of the 31 harbor projects included in the sample (Detroit, Buffalo, and Chicago Districts). Additional samples from within the various project categories were randomly selected for each Division to augment data where survey returns from Districts were substantially lower than average. For example, variation in waterway impacts and costs was much greater in SAD and NWD than in LRD, and the added number of randomly drawn samples was proportionately greater. Using the same criteria used in initial project selection and a limit of two projects per District within the same waterway, 62 additional projects were randomly selected, bringing the total number of sampled projects up to 142 . This resulted in $39.1 \%$ of all projects within the selected divisions being surveyed, with the exception of the Great Lakes harbors.

Operating projects were identified from the Corps' Digital Project Notebook database. The database identifies projects by the stage of 
development and operation (planning, construction, and operations). A few Districts included all of their operating projects under construction and some operating projects were included in the construction category in District databases that sorted the two categories. This required a check of all projects listed under construction on the 1989 map of Corps activities and projects listed in the Annual Report for FY 2003 (U. S. Department of the Army 2004). As a consequence of this problem, some qualifying projects were not included in the original sampled population, but were added for the second round of sampling.

Of 142 project surveys sent out by e-mail to District personnel, 124 responses were received before the study went to full analysis. Of those projects, four were reported to be no longer operated by the Corps and two did not qualify for inclusion (they were local flood protection projects), leaving 118 responses for qualified projects in the survey set. J ust over $91 \%$ of all surveys sent out for qualified projects were ultimately returned by September 21, 2005, the cutoff date for final analysis. From the initial date of survey in J une, three months elapsed during continuous pursuit of a $90 \%$ survey return from two rounds of sampling.

Identifying specific points of contact for project information was not straightforward. Review of District organization and personnel responsibilities at individual projects on the Internet revealed substantial variation among Districts and no consistent programmatic approach to ANS management. The list of P2 project managers was found to be a more useful entry into project-based management and Districts were asked to help with identifying the appropriate personnel for filling out the ANS survey. In most instances the P2 project managers sent the survey form to a more appropriate employee, usually with no notification regarding whom the form was sent to. In the second round of surveys, information was requested about the individuals to whom the survey would be forwarded, but again the response to this request was poor. If two weeks passed without a response to a survey, an e-mail reminder was sent to P2 project managers or their designees. After approximately one week, the email was followed up with telephone calls, with the objective being at least a $90 \%$ survey response. Appendix B lists the projects for which surveys were returned.

It was assumed that the sampled projects were representative of all projects in the three Divisions sampled. A simple mean FY 2004 
expenditure per sampled project was calculated for each District, then multiplied by the total number of freshwater projects in the District to estimate the total District and Division expenditure for freshwater ANS management, including monitoring. No statistical calculations of variance, other than range, or tests of differences among project types and Districts were completed because of the small number of projects reporting expenditures and the wide range of results reported among projects. The information gained also did not lend itself to any more quantification of geographical area of impact than is approximately revealed by the incidence (presence or absence) of reported impacts on services at Corps sites.

\section{Literature review}

Published literature was reviewed to identify information relating to the assessment of ANS problems, management, and management outcomes. The purpose of the review was to summarize relevant ANS impacts, management costs, and outcomes that might be directly or indirectly relevant to the management of Civil Works projects. The review was intended to be broad, but with emphasis on freshwater impacts in the United States. Nuisance species of freshwater algae, vascular hydrophytes (aquatic plants or macrophytes), aquatic amphibians, fish, crustaceans, mollusks, aquatic insects, and other invertebrates were included in the literature search.

A special effort was made to collect quantitative information about how ANS influenced environmental and economic services and associated values at freshwater sites. This included changes in recreational user days, commercial fish harvest rates, commodities shipped, hydropower produced, endangered species population numbers, municipal water treatment costs, and estimates of net economic benefit based on willingness-to-pay concepts, and other relevant measures.

Potentially relevant titles were searched using search terms associated with ANS species categories, service impacts, associated environmental and economic costs, and management actions, costs, and benefits. An online citation index, the Web of Science ${ }^{\circledR}$, was used to search 8,700 scientific journals. Also searched was CSI Illumina, which includes 100 bibliographic and full-text databases. Additional searches were made of invasive-species websites, including the Sea Grant Non-Indigenous Species Site (www.sgnis.org) and the National Aquatic Nuisance Species Clearinghouse 
(www.aquaticinvaders.org). The search included journal publications, book chapters, government reports, and relevant industry reports pertaining to the physical, chemical, and biological impacts of nuisance aquatic species on the operation and maintenance of water resources projects located on inland waters. 


\section{Results}

\section{Survey results}

\section{Survey response}

The numbers of responses and fractions of total projects are summarized in Table 1 for flood control reservoirs, locks and dams and waterways, and lake harbors. Sample size was greatest for flood control reservoirs in all Divisions because of comparatively high project diversity among flood control projects and a relatively high incidence of ANS reported in two of the three divisions. A higher fraction of the flood control reservoirs and waterways were sampled in the NWD and SAD than in the LRD, where there was less variation among Civil Works and reported ANS costs in the first round of sampling. Numerous lock and dam structures occurred in just three waterways (Ohio, Kentucky and Green-Barren Rivers) of the LRD, each of which was sampled at two or more sites with consistent results (no impacts). Because the lock and dam structures within the rivers were similar and closely connected by river flow, a great difference in ANS impacts was not expected. Greater variability in results from waterways of NWD and SAD led to sample larger fractions of these Divisions in the second round of sampling.

There appeared to be no centralized approach to ANS management in most Districts. The exceptions, such as J acksonville District, had major, chronic ANS impacts. It was not always easy for contacted personnel to identify who was most knowledgeable about ANS incidence and manageement at the projects. This problem was most prominent in Districts that ultimately reported no ANS impacts. In general, where there were substantial impacts, responsible parties were more quickly identified and responses were more quickly returned.

\section{ANS occurrence at Corps projects}

Table 2 summarizes the ANS groups identified by common name as nuisances by project type. Large aquatic plants (mostly vascular plants) were most frequently identified (69.1\% of all reports of ANS) as ANS occurring at the sampled Corps projects. A variety of algal and animal ANS comprised the remainder of reported ANS at the sampled Corps projects. 
Table 1. Number of projects and response percent for all freshwater projects within project types and Corps Divisions.

\begin{tabular}{|c|c|c|c|c|}
\hline Division & Flood Control Reservoirs & Locks, Dams \& Waterways & Lake Harbors & Total \\
\hline \multicolumn{5}{|c|}{ LRD $^{1}$} \\
\hline \# of projects & 77 & 71 & 130 & 278 \\
\hline \# in sample & 36 & 14 & 31 & 81 \\
\hline$\%$ in sample & 46.8 & 19.7 & 23.9 & 29.1 \\
\hline \multicolumn{5}{|c|}{$\mathrm{NWD}^{2}$} \\
\hline \# of projects & 44 & 17 & 0 & 61 \\
\hline \# in sample & 21 & 6 & 0 & 27 \\
\hline$\%$ in sample & 47.7 & 35.3 & - & 44.3 \\
\hline \multicolumn{5}{|c|}{$\mathrm{SAD}^{3}$} \\
\hline \# of projects & 14 & 15 & 0 & 29 \\
\hline \# in sample & 8 & 8 & 0 & 16 \\
\hline$\%$ in sample & 57.1 & 53.3 & - & 55.2 \\
\hline \multicolumn{5}{|c|}{ Total } \\
\hline \# of projects & 135 & 103 & 130 & 368 \\
\hline \# in sample & 65 & 28 & 31 & 124 \\
\hline$\%$ in sample & 48.2 & 27.2 & 23.9 & 33.7 \\
\hline \multicolumn{5}{|c|}{$\begin{array}{l}{ }^{1} \text { Great Lakes and Ohio River Division } \\
2 \text { South Atlantic Division } \\
{ }^{3} \text { Northwestern Division }\end{array}$} \\
\hline
\end{tabular}

Table 2. Number of times each ANS category was identified as being recently present at Civil Works projects by project category.

\begin{tabular}{|l|l|l|l|l|}
\hline ANS & $\begin{array}{l}\text { Flood Control } \\
\text { Reservoirs }\end{array}$ & $\begin{array}{l}\text { Locks \& Dams \& } \\
\text { Waterways }\end{array}$ & Harbors & Total \\
\hline Algae & 6 & 2 & 0 & 8 \\
\hline Large aquatic plants & 5 & 8 & 0 & 13 \\
\hline Fish & 5 & 2 & 0 & 7 \\
\hline Mussels or clams & 0 & 3 & 0 & 3 \\
\hline $\begin{array}{l}\text { Water fleas or } \\
\text { crayfish }\end{array}$ & 1 & 0 & 0 & 1 \\
\hline Biting insects & 0 & 0 & 0 & 0 \\
\hline Other & 0 & 0 & 0 & 0 \\
\hline All ANS & 17 & 15 & 0 & 32 \\
\hline
\end{tabular}


No biting insects or other species were reported to be ANS. Most ANS were encountered in impoundments built for flood control and navigation improvement purposes, primarily because they make up a large fraction of the sampled project sites. In flood control reservoirs alone, fish and algae were identified as ANS slightly more frequently than aquatic vascular plants. Few incidents of ANS were identified at Great Lake harbors and all of those were zebra mussels. In general, ANS were more likely to be identified at large multipurpose projects and long waterways than at small flood control projects, harbors, or locks and dams.

One or more ANS were identified at 21 (16.9\%) of the sampled Corps projects. Two or more ANS groups were identified at 7 projects (5.7\%). The total number of projects where ANS were reported was similar at flood control reservoirs and at locks and dams and waterways, but the fraction of waterway projects colonized (28.1\%) was about twice that of reservoirs (13.7\%). Aquatic vascular plants greatly predominated among the ANS reported in waterways, where fish, clams, and algae were much less frequently identified as nuisances. Greater incidence of fish and algae ANS occurred at flood control reservoirs (Table 2), but, overall, each frequented only $6.5 \%$ of the sampled projects. Nuisance water fleas were the target of monitoring activity at one (1.4\%) of the flood control reservoirs. No ANS were identified to be a project problem at the sampled lake harbors although zebra mussels were incidentally reported as boater nuisances for Lake Erie sites. "Other" was reported at several sites, but all were terrestrial species and excluded from the analysis. There were no "other" ANS reported.

Table 3 provides a more detailed list of the identified ANS. Algae were rarely differentiated to species or even to major taxonomic group. Bluegreen algae were identified as a periodic problem at two of the flood control reservoirs. Of the nuisance vascular plants, hydrilla, water hyacinth, and Eurasian watermilfoil were most often reported as the prominent ANS. Assuming correct common name identification, most of the identified plant ANS were alien species (Fassett and Ogden 2006) and all occurred outside their native range at the projects where they were considered a nuisance. The six fish species identified at the sample projects are all native to the United States (Bailey and Robins 1991). If identified properly, only three - the American shad (Alosa sapidissima), brook trout (Salvelinus fontinalis), and white perch (Morone chrysops) were outside their native range at the projects where they were identified 
Table 3. ANS identified at project sites (whether or not operations funds were spent). Usually, only common names were reported and no attempt was made to verify the accuracy of the reports.

\begin{tabular}{|c|c|c|}
\hline ANS & Number of Projects & Percent of Projects \\
\hline Algae & 8 & 6.5 \\
\hline Blue-green algae & 2 & 1.6 \\
\hline Large aquatic plants & 13 & 10.5 \\
\hline Hydrilla & 4 & 3.2 \\
\hline Water hyacinth & 3 & 2.4 \\
\hline Eurasian watermilfoil & 3 & 2.4 \\
\hline Common reed & 2 & 1.6 \\
\hline Curly leaf pondweed & 2 & 1.6 \\
\hline Purple loosestrife & 2 & 1.6 \\
\hline Water primrose & 2 & 1.6 \\
\hline Giant cutgrass & 1 & 0.8 \\
\hline Water lettuce & 1 & 0.8 \\
\hline Cuban bulrush & 1 & 0.8 \\
\hline Fish & 7 & 5.7 \\
\hline Brook trout & 1 & 0.8 \\
\hline Gizzard shad & 1 & 0.8 \\
\hline Yellow bass & 1 & 0.8 \\
\hline White perch & 2 & 1.6 \\
\hline American shad & 1 & 0.8 \\
\hline Northern pikeminnow & 1 & 0.8 \\
\hline Freshwater clams & 3 & 2.4 \\
\hline Asiatic clam & 3 & 2.4 \\
\hline Waterfleas and crayfish & 1 & 0.8 \\
\hline Spiny water flea & 1 & 0.8 \\
\hline Biting insects & 0 & 0 \\
\hline Other & 0 & 0 \\
\hline
\end{tabular}

to be a nuisance (Fuller et al. 1999). The northern pikeminnow (Ptychocheilus oregonensis) is considered a nuisance in western impoundments on the Columbia/ Snake River where it eats salmon (Fuller et al. 1999). The gizzard shad (Dorosoma cepedianum) and yellow bass (Morone mississippiensis), native species in the Mississippi drainage (Fuller et al. 1999), compete for the food of desirable game species (some of which may not be native species) in some reservoirs. 
Survey results were compared to invasive species reported at Corps projects surveyed in the Operations and Maintenance Business Information Link (OMBIL) database for environmental stewardship as of 15 September 2005. The OMBIL survey reports include an estimate of relative abundance (e.g., rare, common, abundant) and acreage impacted by invasive species.

In the $\mathrm{SAD}$, neither Charleston nor J acksonville Districts appeared to have reported any invasive species for any project, indicating that they had yet to complete the OMBIL survey for invasive species at projects. Otherwise, where OMBIL reports were available, they were, in general, consistent with the reports collected for this study. For example, OMBIL and the project survey concur that hydrilla and water hyacinth were common to abundant in the Black Warrior and Tombigbee Rivers project, and at Walter F. George Lock and Dam project. OMBIL reports indicated no abundant populations of ANS at three other Mobile projects, all of which reported no impacts in the project survey. Hydrilla was reported to have an impact at J. Strom Thurmond Dam and Lake in both OMBIL and the project survey. OMBIL also confirmed no-impact reports for Hartwell Dam and Lake in the project survey. At Falls Lake, a small biological survey of what may be a growing hydrilla ANS impact was reported in the project survey and corroborated with identification of common occurrence in OMBIL. Similarly, both surveys reported no ANS occurrence of impact dimensions at J ohn H. Kerr Dam and Reservoir.

However, there were two situations where the results appeared to deviate. Asiatic clam was indicated as a possible threat to endangered species at the East Fork of the Tombigbee River project in the project study, but is not mentioned in the OMBIL survey. The Asiatic clam (Corbicula fluminea) has been documented as common in the vicinity (e.g., Miller 1988). At Philpott Lake, OMBIL identified alewife (a native fish species) as abundant, but it was not reported as an ANS in the project survey. Alewife (Alosa pseudoharengus) is typically abundant where it occurs and may become either a nuisance (it sometimes competes with endangered species and dies en masse and sullies shorelines) or a beneficial forage species for game and commercial species (Cole 2005).

The general absence of reported ANS impacts at LRD projects showed up in OMBIL reports as well. There were few other exceptions at flood control reservoirs and at locks and dams (which also may not have a stewardship 
function). Alewife in Lake Cumberland and zebra mussels in Mosquito Creek Lake (Ohio), reported to be common in OMBIL, were not reported to be nuisances in the project survey. Asian tiger mosquitoes were also indicated to be common at Lake Barkley and Lake Cumberland, but were not identified as nuisances in the project study (no biting insects were identified as ANS).

Most of the reports from the two surveys aligned quite well for the Northwestern Division. However, OMBIL reported no invasive species for several lakes where non-native fish (brook trout, northern pikeminnow, yellow bass, and white perch) and algae were reported to cause ANS impacts in the project survey. Some of these nuisances were caused by native species, probably explaining some of the difference. One exception was at J ohn Day Lock and Dam, where there was no OMBIL report for any invasive species even though American shad, watermilfoil (probably Eurasian watermilfoil), curly leaf pondweed, and Asiatic clams were reported to cause ANS impacts in the project study. These species appear to be common in Columbian River lock and dam impoundments sampled in the survey. American shad was introduced to the Columbia from the east coast (Fuller et al.1999). The same species were identified at the Bonneville Lock and Dam project in the project survey, whereas only Eurasian watermilfoil was identified as common in the OMBIL report.

In summary, there were some differences in the two reports, but, by and large, the results were quite consistent at projects where OMBIL reports identified at least one invasive species. Some differences probably resulted because the ANS were not considered to be invasive species in the OMBIL report, such as native fish and algae. In a few other cases, species may be common but not recognized as causing an impact. Other reports from the project survey tended to reveal impacts that were not necessarily associated with the recreational areas and natural resource management activities often linked to the environmental stewardship business line in OMBIL. This is described in more detail in the next section.

\section{Service impacts at Corps projects}

Table 4 lists impacts, categorized by the services they affected at projects. The highest percentage of projects impacted within a service category reported observed degradation of recreational services (10.5\%). About $62 \%$ of all projects with reported impacts had experienced recreational impacts. Recreational boating was most frequently identified as impaired 
Table 4. Number of projects and percent of projects at which services were reported impacted in the three Corps Divisions sampled.

\begin{tabular}{|l|l|l|}
\hline Service & Total & Percent of Sampled Projects \\
\hline Recreation & 13 & 10.5 \\
\hline Boating & 8 & 6.5 \\
\hline Swimming & 5 & 4.0 \\
\hline Fishing & 5 & 4.0 \\
\hline Aesthetics & 1 & 0.8 \\
\hline Environmental & 6 & 4.8 \\
\hline Navigation & 3 & 2.4 \\
\hline Hydropower & 2 & 1.6 \\
\hline Drinking water quality & 1 & 0.8 \\
\hline Irrigation water supply & 1 & 0.8 \\
\hline Total Projects Impacted & 21 & 16.9 \\
\hline
\end{tabular}

by ANS, followed by fishing and swimming. Diminished site aesthetics was indicated at one project. Recreational boating was the only service reported to be impacted by ANS at harbor projects, where zebra mussels colonized recreational boat hulls.

Environmental services were perceived to be degraded at nearly $5 \%$ of all projects sampled and about one third of the projects reported impacts from ANS. Most of the reported environmental impacts also exacerbated threats faced by species listed as threatened or endangered under the Endangered Species Act. Some impacts were identified more generally as threats to natural wetland conditions.

Of the Corps projects in the sample reporting ANS impacts on project services, navigation was impacted at $14.3 \%$ of the sites, all the result of large aquatic plants in the SAD projects. Aquatic plants, Asian clams, and American shad decreased hydropower production efficiency at $9.5 \%$ of the impacted projects (multipurpose projects in the Columbia River system), where they required routine removal from trash racks protecting generator penstocks. At J ohn Day Lock and Dam (Lake Umatilla), OMBIL did not report any invasive species even though Asian clams, American shad, and Eurasian watermilfoil clogged trash racks protecting penstocks to power generators. Drinking water quality maintenance and agricultural water supply were impacted at only one project each. 


\section{Management actions and expenditures}

In FY2004, over \$4 million was reported to have been spent at Civil Works projects on ANS management in the surveyed Divisions (Table 5). Most of the cost was incurred for management of aquatic plants. Half of all projects (12 of 24) for which some form of ANS impact was noted also reported that no funds were spent on ANS management in FY2004 or requested for FY2005. Most of these ANS were fish, mussels, or algae. Other government agencies paid for fish management in some instances, including management of recreational fisheries at one flood control reservoir, and management of northern squawfish in a Snake River project. Algae and large plants were noted ANS at several projects, but not enough to warrant recent past (FY2004) or present (FY 2005) management. Two small expenditures covered monitoring for algae and plants at one flood control reservoir and for white perch and spiny water fleas at another flood control project. Unless this type of cost was generally overlooked at half the projects with reported impacts, the noting of ANS at projects in the absence of ANS management expense was most likely an incidental outcome from other management activities bearing the operation expense.

Table 5. Reported ANS management costs (\$) by ANS category and project type for FY2004.

\begin{tabular}{|c|c|c|c|c|}
\hline ANS & $\begin{array}{l}\text { Flood Control } \\
\text { Reservoirs }\end{array}$ & $\begin{array}{l}\text { Locks \& Dams \& } \\
\text { Waterways }\end{array}$ & Lake Harbors & Total \$ \\
\hline Algae & 50,000 & 0 & 0 & 50,000 \\
\hline Aquatic plants & 20,000 & $4,082,500^{1}$ & 0 & $4,102,500$ \\
\hline Fish & 0 & 02,3 & 0 & 0 \\
\hline Mussels or clams & 0 & $0^{2}$ & 0 & 0 \\
\hline Water fleas/crayfish & 0 & $5,000^{3}$ & 0 & 5,000 \\
\hline Biting insects & 0 & 0 & 0 & 0 \\
\hline Other & 8,000 & 0 & 8,000 & 8,000 \\
\hline All ANS & $\$ 70,000$ & $\$ 4,087,500$ & 0 & $\$ 4,165,500$ \\
\hline \multicolumn{5}{|c|}{$\begin{array}{l}1 \text { Includes } \$ 70,000 \text { for removing fish (American shad) and Asiatic mussels in addition to aquatic plants from trash racks } \\
\text { for hydropower penstocks, and aeration for algae control at McNary, John Day, and Bonneville lock and dams. }\end{array}$} \\
\hline \multicolumn{5}{|c|}{$\begin{array}{l}2 \text { Fish and Asiatic clams were removed from trash racks with aquatic plants at Columbia River projects ( } \$ 70,000 \text { total } \\
\text { expense) }\end{array}$} \\
\hline \multicolumn{5}{|c|}{${ }^{3} \mathrm{~A}$ total of $\$ 5,000$ was spent on monitoring water fleas and white perch. } \\
\hline
\end{tabular}


Personnel at 12 projects (9.7\% of project survey responses) reported expenditures for ANS management (Table 6). ANS costs reported for individual projects ranged from $\$ 2,000$ to $\$ 2,300,000$ in FY 2004. Over $\$ 1$ million was spent in FY 2004 at two projects. From \$100,000 to $\$ 1,000,000$ was spent at just one sampled project. From $\$ 10,000$ to $\$ 100,000$ was spent at six projects. ANS management costs under $\$ 10,000$ were incurred at three projects. Nearly $98 \%$ of all ANS expenditures occurred within $\mathrm{SAD}$, with nearly all those funds spent on control of large aquatic plants. The rest was spent in NWD to manage a variety of impacts from algae, large plants, fish, and Asiatic clams. Over half of these NWD expenses were associated with algal impacts at one lock and dam impoundment and one flood control reservoir, both of which were mixed by aeration to remove phosphorus

Most of the remaining NWD ANS expenditures were associated with mechanical removal of fish (American shad; an exotic species), Asiatic clams, and large aquatic plants from penstock trash racks in multipurpose lock and dam impoundments on the Columbia River.

ANS management expenses were reported for only one LRD project (for monitoring purposes). The largest expenditures occurred at lock and dam and waterway projects. No expenditures were reported at any of the sampled freshwater harbors. ANS impacts appear to be chronic and management costs somewhat routine, as FY2005 requests were very similar to the reported expenditures for FY2004. The most consistent expenses address chronic infestations of nuisance aquatic plants in waterways. Rarely was management planned for FY2005 that had not been included in the operation budget for FY2004. Most projects with small FY2004 expenses reported that no ANS management budget had been requested for FY2005. One major exception was a request for $\$ 47,000$ at J. Strom Thurmond Reservoir (Savannah District), an increase from an FY2004 expenditure of $\$ 18,000$. 
Table 6. Reported operations expenditures (\$) for managing ANS impacts in 2004 and budgeted for 2005 by ANS category and project type summed for all three Divisions studied

(LRD, NWD, and SAD).

\begin{tabular}{|c|c|c|c|c|c|}
\hline District/Project & $\begin{array}{l}\text { Flood Control } \\
\text { Reservoirs } \\
61 \text { sampled }\end{array}$ & $\begin{array}{l}\text { Locks \& Dams } \\
\text { \& Waterways } \\
26 \text { sampled }\end{array}$ & $\begin{array}{l}\text { Lake Harbors } \\
31 \text { sampled }\end{array}$ & $\$ F Y 2004$ & $\$ F Y 2005$ \\
\hline \multicolumn{6}{|l|}{ Pittsburgh } \\
\hline Kinzua Dam & $\mathrm{X}$ & & & 5,000 & - \\
\hline \multicolumn{6}{|l|}{ Portland } \\
\hline Bonneville & & $x$ & & 25,000 & 0 \\
\hline John Day & & $x$ & & 30,000 & 0 \\
\hline Willow Creek Lake & $X$ & & & 50,000 & 0 \\
\hline Albeni Falls & $\mathrm{X}$ & & & 8,000 & 2,000 \\
\hline \multicolumn{6}{|l|}{ Walla Walla } \\
\hline Little Goose & & $\mathrm{x}$ & & 2,500 & - \\
\hline McNary & & $x$ & & 15,000 & - \\
\hline \multicolumn{6}{|l|}{ Jacksonville } \\
\hline Okeechobee Waterway & & $\mathrm{X}$ & & $1,200,000$ & $1,200,000$ \\
\hline St. Johns River & & $x$ & & $2,300,000$ & $2,400,000$ \\
\hline \multicolumn{6}{|l|}{ Mobile } \\
\hline Black Warrior/Tombigbee & & $x$ & & 60,000 & 50.000 \\
\hline Walter F. George L\&D & & $x$ & & 450,000 & \\
\hline \multicolumn{6}{|l|}{ Savannah } \\
\hline J. Strom Thurmond & $x$ & & & 18,000 & 47,000 \\
\hline \multicolumn{6}{|l|}{ Wilmington } \\
\hline Falls Lake & $x$ & & & 2,000 & 0 \\
\hline Totals & 4 & 8 & 0 & $\$ 4,165,500$ & $\$ 3,679,000$ \\
\hline
\end{tabular}

Approximations of total ANS management costs accrued across the three Corps Divisions were developed for FY2004 by calculating the average costs of projects within Districts and multiplying by the number of projects in each project category. In 2004, an estimated \$5 million was spent on ANS management across all freshwater projects in SAD, NWD, and LRD. Table 6 shows reported project ANS management costs and Table 7 summarizes the estimated total costs for those Districts for which some management expense was reported. Certainty of the estimates varies among the Districts. The $\$ 3.5$ million estimated spent in qualifying freshwater projects in the J acksonville District is comparatively certain, because nearly all of the waterway system in that District was included in the survey. Respondent estimates of total District spending were also 
identical to the sum for the two projects (St. J ohns River and Okeechobee Waterway). The estimate for Mobile District is substantially less certain because only $44 \%$ of the projects were included in the sample and reported expenditures ranged widely between $\$ 0$ and $\$ 450,000$. The relatively small sample of returned surveys for Portland flood control projects (21\%) and Walla Walla Locks and Dams and Waterways (25\%) resulted in greater uncertainty in those estimates than the estimates obtained for Portland District Locks and Dams and Waterways (57\% reporting), Savannah District projects (67\% reporting), and Wilmington District projects (60\% reporting).

Table 7. Estimated total ANS management cost (\$) for FY 2004 by District and project type in the SAD, NWD, and LRD.

\begin{tabular}{|c|c|c|c|c|}
\hline Division/District & \begin{tabular}{|l|} 
Flood Control \\
Reservoirs
\end{tabular} & $\begin{array}{l}\text { Locks \& Dams \& } \\
\text { Waterways }\end{array}$ & Lake Harbors & Total \\
\hline LRD & 6,670 & 0 & 0 & 6,670 \\
\hline Buffalo & 0 & 0 & 0 & 0 \\
\hline Chicago & 0 & 0 & 0 & 0 \\
\hline Detroit & 0 & 0 & 0 & 0 \\
\hline Huntington & 0 & 0 & 0 & 0 \\
\hline Louisville & 0 & 0 & 0 & 0 \\
\hline Nashville & 0 & 0 & 0 & 0 \\
\hline \multirow[t]{2}{*}{ Pittsburgh } & 6,670 & 0 & 0 & 6,670 \\
\hline & 233,330 & 166,250 & 0 & 399,580 \\
\hline \multicolumn{5}{|l|}{ NWD } \\
\hline Kansas City & 0 & 0 & 0 & 0 \\
\hline Omaha & 0 & 0 & 0 & 0 \\
\hline Portland & 233,330 & 96,250 & 0 & 329,580 \\
\hline Seattle & 8,000 & 0 & 0 & 8,000 \\
\hline \multirow[t]{2}{*}{ Walla Walla } & & 70,000 & 0 & 70,000 \\
\hline & 30,335 & $4,647,500$ & 0 & $4,677,835$ \\
\hline \multicolumn{5}{|l|}{ SAD } \\
\hline Charleston & 0 & 0 & 0 & 0 \\
\hline Jacksonville & & $3,500,000$ & 0 & $3,500,000$ \\
\hline Mobile & & $1,147,500$ & 0 & $1,147,500$ \\
\hline Savannah & 27,000 & & & 27,000 \\
\hline Wilmington & 3,335 & & 0 & 3,335 \\
\hline Total & $\$ 278,335$ & $\$ 4,813,750$ & 0 & $\$ 5,092,085$ \\
\hline
\end{tabular}




\section{Literature review}

\section{Synthesis literature}

Among the synthesis reports, OTA (1993) and Pimentel et al. (2000) are among the most frequently cited of those that address economic impacts of ANS. Both reports attempt to compile existing information in order to estimate the total impact of invasive species to the U.S. economy. Freshwater ANS make up a small fraction of the total ANS covered in the two reports. Neither addresses the costs of native species outbreaks or "blooms" that elevate them to ANS status in ecologically disturbed circumstances. Both reports provide a breakdown of economic impacts by type of ANS species or service sector. The estimates of economic impacts in these two reports vary greatly, and in some cases the basis for the cost estimates is not found in the document cited. One explanation for the variability was suggested by Perrings et al. (2000), who noted that not all impact components are represented, and each of the innumerable components is "subject to considerable errors that are compounded in the summation." These and similar studies generally lacked a systematic empirical method for calculating ANS economic impacts. The need for a more systematic approach has been noted by others, including Perrings et al. (2000), Government Accounting Office (GAO) (2002), and Lovell and Stone (2005).

Freshwater ANS impacts exist across the United States, but, judging by the emphases in the existing literature, the most significant economic impacts have occurred in the eastern United States, particularly in the Great Lakes and in the southern states. This may not be so true for environmental impacts (Cole 2005). Based on the literature, those ANS with the greatest impacts on freshwater environmental services and values include fish, mussels, and large aquatic plants. Most ANS in the Great Lakes are animal species, although filamentous algae (e.g., Cladophora spp.) are a common local nuisance. In the South, certain species of aquatic vascular plants are the most commonly encountered ANS. Certain microbial ANS are more generally distributed across the United States, including the sporadic impacts of toxic blue-green algae and certain pathogenic protozoa and viruses, but these are less frequently the object of recent publications. They can have local impacts of substantial cumulative impact across the nation, but have not garnered the attention recently paid in the published literature to alien plants, fish, and freshwater clams. 
The sea lamprey (Petromyzon marinus) has long been recognized as an ANS of significant economic impact in the Great Lakes and has been treated accordingly through programs dedicated to its control (Fuller et al. 1999). It is native along the coasts and gained access to the Great Lakes through canal construction. More recent nuisance fish invasions are more typically from other continents. The Baltic Sea, Atlantic Ocean, and St. Lawrence Seaway represent one of the most important pathways for entry of animal ANS to U.S. freshwaters, with ship ballast water serving as the primary means of transfer from points of origin near the Baltic Sea. Sport and commercial fisheries have suffered significant economic losses from the introduction of nuisance fish into U.S. freshwaters.

Several species of dreissenid mussels (zebra mussels, Dreissena polymorpha, and congeneric species), also transported from the Baltic region, have caused more costly impacts than other recently invasive, nonnative ANS. They are now among the most widespread of the animal ANS, having colonized much of the Mississippi River system via the Chicago Sanitary and Ship Canal, which links the Great Lakes and Illinois River. Dreissenid mussels clog water intakes for drinking water, power plants, and other uses and have greatly impacted ecosystems and possibly depressed native mussel species abundances in the Great Lakes and elsewhere (e.g. Brown 2001). While not as yet fully defined, they have the potential to cause significant changes in economic and environmental services and values of the aquatic ecosystems they colonize.

A wide variety of methods are now used to control the animal ANS that have invaded the Great Lakes and beyond, which have in the case of sea lamprey been integrated into comprehensive strategic plans facilitated in their implementation by a single international organization, the Great Lakes Fishery Commission. Zebra mussels, in contrast, are most often treated at the site of impact by diverse interests using diverse methods and acting for the most part independently of one another.

Nuisance aquatic vascular plants are nearly ubiquitous in small lakes and in littoral areas of large lakes and waterways developed for inland navigation, but are especially problematic in the southern states. A few species dominate the ANS literature including hydrilla (Hydrilla verticillata), Eurasian watermilfoil (Myriophyllum spicatum), purple loosestrife (Lythrum salicaria), water hyacinth (Eichhornia crassipes), and giant salvinia (Salvinia molesta). Much of the literature on nuisance plant 
species was published before more recent invasions of animal nuisance species captured attention. The economics of vascular plant management and impacts are also, in general, more thoroughly developed. Dense growth of aquatic plants interferes with boating, fishing, swimming, and other recreation; aggravates flooding; and increases costs of domestic water treatment and commercial navigation. Aquatic plants also greatly modify the ecosystem pathways and species composition, sometimes to the detriment of ecosystem services in support of endangered species. Similar to animal ANS in the Great Lakes, the most damaging large aquatic plants are of foreign (especially Eurasia and South America) origin. Various methods are used to control vascular aquatic plants, which vary widely in cost and effectiveness.

In general, ANS impacts have been reacted to largely by local interests who treat the symptoms or limit the spread of ANS locally rather than by eliminating the sources of impacts more generally. Sea lamprey control has been an exception to the rule, in part because most damages are confined to the Great Lakes. It also has been among the most successful ANS management programs. Substantial investments in sea lamprey impact management are evidence of local and regional belief that economic and environmental impacts are large and worth the investment. In the case of the sea lamprey, a better case for costly control efforts can be made to the public because concerted efforts have been made to assess both ecological and economic impacts.

While often documented as changes in ecosystem structure and function, the ultimate effects of ANS impacts on environmental services are even less well quantified in terms of service degradation and lost values. Change is a characteristic of natural as well as humanly influenced ecosystems, and is not necessarily an indicator of service depreciation and lost value. Despite undoubtedly large changes in Great Lakes communities (Cole 2005), it is not clear that any extant species is substantially more threatened with global extinction as a consequence, although some may be. Many of the economic studies lack a systematic empirical method for estimating economic impacts, are not well-documented, or are not inclusive of all potential impacts.

Incomplete and sometimes inaccurate information is often characteristic of reports on ANS management. The reported estimates of management costs in the reviewed synthesis reports are repeated in various forms 
throughout the literature, often without supporting information or a description of what the costs represent. The costs are misrepresented in some cases; for example, the Sea Grant Clearinghouse study on zebra mussels (O'Neill 1997) reported that 339 facilities in the United States and Canada reported total mussel related expenses from 1989 to 1995 of $\$ 69$ million. This figure is often misrepresented in the literature as the total cost of zebra mussel control in the United States during that period (see, for example, GAO 2002). For this reason, the original source of an estimate should be obtained and reviewed before it is used.

The most abundant and specific information on ANS-related costs reported in the synthesis literature related to costs incurred in managing a particular ANS problem. The cost of treating for zebra mussels at hydropower plants is a case in point. The costs to hydropower may be described per plant, by treatment type, kilowatt-hour, or some other metric. Also, some costs are presented in Canadian dollars, or are from older studies and need to be converted to present-day dollars. Economic contexts have often changed as well, however, calling into greater question how accurately older studies represent contemporary circumstances that now determine economic value. A major challenge in using the damage costs reported in the synthesis literature for planning or decision-making at program levels is resolving differences associated with the various forms of cost reporting. This fragmented approach to estimating damage and management costs can lead to inaccurate estimates of total costs, especially when management of different species may result in antagonistic or synergistic effects.

The reported ANS damage costs do not generally include costs related to the ecological impacts from ANS invasions, which can be manifested as a change in ecosystem structure and function. Ecosystem functional processes that can be altered by an ANS invasion include: competition for food and habitat, predation on indigenous organisms, food chain selectivity impacts, loss of forage base, disruption or alteration of energy flow through the food web, disruption or alteration of nutrient cycling, and disruption or alteration of habitat. As a result of these impacts, many ANS invasions have the potential to reduce biodiversity in a given ecosystem by causing the extirpation of a native species. Wilcove et al. (1998) quantified the threats posed to imperiled species by habitat destruction, alien species, overharvest, pollution (including siltation), and disease, and concluded that both competition with and predation by invasive species are major threats to imperiled species. 
Quantifying economic values for services relating to biodiversity, human health, existence of endangered species, and other ecosystem services in support of these and other resource uses is difficult and often controversial. RNT Consulting, Inc. (2002) notes that the estimates of ANS economic impacts reported to date do not include potential human, social, and environmental costs because of a lack of economic measurement tools for these effects. Leung et al. (2002) observed that non-market evaluation, while challenging, should be considered in estimating the economic impacts of ANS, because policyholders need more information about probable values attached to ecological services. Therefore, even the very large estimates of the economic impacts reported in the current literature may be underestimates of the total economic impact of ANS.

Despite the shortcomings of the large synthesis papers, they do demonstrate that the magnitude of economic impact of ANS is substantial, and provide a perspective on the broad categories of how costs are being expended. For example, according to one estimate, based on multiple individual cost estimates (Pimentel et al. 2005), the environmental and economic impacts of biological invaders in the Great Lakes Basin is $\$ 5.68$ billion. About $\$ 4.5$ billion of this (about $80 \%$ ) is related to impacts of nuisance fish on commercial and sport fisheries.

\section{Specific literature}

Dreissenid mussels. The dreissenid mussels have important economic and environmental impacts. Through biofouling of water intakes and other structures, dreissenids have detrimentally impacted virtually every user of surface waters in areas where these species have become established. Control technologies include various forms of physical and chemical treatments. On a nationwide basis, the power industry alone spent approximately \$60 million per year on zebra mussel control and increased maintenance costs in the 1990s (GAO 2002; OTA 1993). Pimentel et al. (2005) estimate the economic costs (including economic impacts and management costs) of zebra mussels at $\$ 1$ billion per year in the United States. Another study has estimated that the economic costs associated with dreissenids would reach $\$ 5$ billion by about 2010 (GlassnerSchwayder 2000). This estimate includes all maintenance, control, and impact costs associated with the zebra mussel invasion. The annual management cost of zebra mussel control is expected to increase as the number of affected water bodies increases. 
Lampreys and other fish. The fish species receiving much of the attention in the literature are the sea lamprey, Eurasian ruffe (Gymnocephalus cernuus), bighead carp, (Hypophthalmichthys nobilis), round goby (Neogobius melanostomus), and giant snakehead (Channa micropeltes). Some of the most significant impacts, and much of the research, have occurred in the Great Lakes Basin. The overall cost of the sea lamprey control program in the United States and Canada is reported to be approximately \$10 million (Glassner-Schwayder 2000) to \$13 million (J enkins 2001) per year. This estimate does not include economic losses associated with past massive declines in populations of economically important fish species due to sea lamprey parasitism (e.g., Heinrich et al. 2003).

While sea lamprey have not been eliminated, the control program has been highly effective, with an estimated benefit-cost ratio of about 15 to 1 (MacIsaac et al. 2002). The program should serve as a model for other invasive species management plans. Cost estimates for the other species are more limited, and the literature reflects concerns about potential losses in the future much more so than losses already incurred. There is also a body of literature on fish pathogens that impact commercial and recreational fishing, but economic information on these impacts is limited.

Aquatic weeds and algae. Nuisance aquatic vascular plants (aquatic weeds) are a major and ubiquitous problem in small lakes and shallow waters of large lakes throughout the United States, with some of the most significant impacts in southern states. Expenditures for aquatic vascular plant control are large and, because the control measures generally do not eliminate underlying contributors to infestation (e.g., altered hydraulics, high nutrient loads, accelerated sedimentation, colonization sources) these management costs recur on an annual basis in most systems. By one estimate, approximately \$155 million is spent annually for the control of non-indigenous aquatic weed species including purple loosestrife (OTA 1993). In Florida alone, where nuisance aquatic plants have invaded $96 \%$ of public lakes and rivers, the state spent \$25 million in FY 2003-2004 to control invasive plants in public lakes and rivers (Florida Department of Environmental Protection 2003).

Another major class of aquatic nuisance flora is freshwater algae. Excessive growth of nuisance algae, often caused by high nutrient loadings, can negatively impact tourism, real estate values, municipal services, and 
human health. The management and treatment of nuisance algae is performed via a number of different techniques, including chemical control, mechanical and physical control (e.g., whole lake mixing by aeration), biological control, and cultural control methods. Watershed management has proven in some cases to be an effective and long-term management option that controls the problem at its sources. The control costs for this class of nuisance organism are very difficult to estimate. However, in one case, the British Columbia Auditor General estimated that adding filtration systems to smaller water systems outside Vancouver and Victoria would cost approximately CDN \$700 million to install and $\$ 30$ million annually for operation and maintenance.

Pathogens. Water-borne pathogens include bacteria, viruses, and protozoans. Recently, West Nile virus (Flavivirus sp.), a pathogen transmitted by mosquitoes, has become a human pathogen of concern (O'Leary et al. 2004; Zohrabian et al. 2004). Water-borne pathogens are generally associated with waters polluted from urban runoff and improper wastewater treatment practices such as combined sewer overflows (Glasner and McKee 2002). Human pathogens of greatest concern in the United States are generally those that are contracted through exposure in recreational waters or that are resistant to conventional drinking water treatment practices (Glasner and McKee 2002). Swimming-related illnesses are not usually fatal but are significant in terms of the economic costs associated with sick days and medical care. Economic impacts of waterborne pathogens also include losses from beach closings and associated swimming prohibitions. Beach closings at one Lake Michigan beach resulted in an estimated economic loss ranging from \$1,274 to $\$ 37,030$ per day (Rabinovici et al. 2004). Current management practices that address water-borne pathogens include monitoring, testing, and beach closings.

The specific literature provides a great deal of useful information about various ANS, their impacts and geographic distributions, environmental and economic services affected, and management measures. Some information on economic impacts and management costs is available, but this type of information is more limited and the studies generally lack a systematic empirical method for estimating costs. The literature also highlights a need for a coordinated and consistent nationwide effort at prevention and control of ANS. 


\section{Discussion}

\section{Approach to the project survey}

The survey results revealed a wide range of management costs among Corps projects. As a consequence, there is substantial uncertainty in estimated management costs in certain Districts. Sampling always runs the risk that very large expenditures at single projects, such as those in J acksonville District, might be missed, leading to a significant underestimation of the total management cost. However, discussions with Corps personnel and background information provided by the literature review are likely to have revealed where the greatest problems and expenses might occur, and sampling intensity was adjusted accordingly. The incidence of ANS reported at Corps-operated projects is reasonably precise for the three Divisions sampled, and estimated management costs in the J acksonville District, where three of the four freshwater projects were sampled, is also quite precise. Because most ANS management cost was incurred in that District, the total estimated expenditure in all three Divisions is more precise than indicated by the wide range of reported expenditures. The results certainly provide information well within an order of magnitude; for example, Operation and Maintenance expenditures on ANS in the three Divisions during FY2004 are in the low millions of dollars. However, certainty in the results might be improved by follow-up interviews with the identified ANS specialists.

One of the lessons learned during the course of the study was that information about major ANS impacts and expenditures at Corps projects, which are relatively uncommon occurrences or events, was highly decentralized. Other similarly specialized types of information are likewise suspected to be decentralized and difficult to collect. Identifying those personnel most knowledgeable about ANS conditions and spending at Corps projects took more time than initially estimated for some projects. A survey of District websites quickly confirmed that there is no standard organization or identifiable assignment of ANS management issues at a District level. It was discovered, however, that the new $\mathrm{P} 2$ database provided a project manager name; project managers could serve as a common starting point in identifying more knowledgeable personnel. When available, they typically responded as quickly as schedules allowed by sending the surveys on to more appropriate personnel, through a chain 
that usually identified the most knowledgeable person quite quickly. More often than not, there was no indication of who the e-mail was sent to, even though that information was explicitly requested in the full survey. This required follow-up on unanswered surveys through the original contact, which prolonged the process. Getting personnel to copy on e-mail chains should be beneficial to all parties concerned, if it saves time. This concept may need to be clarified in future surveys.

In those instances where P2 managers were not available (e.g., on leave), the District branch chief most knowledgeable about ANS issues was contacted. This included chiefs of flood control, navigation, operations, or environmental branches, depending on particular District organizational structures. Since the projects serve a variety of purposes, no single branch chief is universally informed about ANS at all projects. However, in many cases, chiefs of environmental branches seemed to be the best initial sources of information. Working through branch chiefs resulted in all District project surveys being routed through a single person, which seemed, on average, to slow the rate of survey return relative to working through project managers identified in P2.

The (unavoidable) timing of the survey may have contributed to response delays and the need to do more telephone follow-up than might be required at other times of the year. The late spring and summer months are preferred times for District personnel to conduct field work or take personal leave. Regardless of when a survey is administered to Corps personnel, at least three months should be allowed to assure a high survey response and any necessary follow-up.

Information on invasive species at Corps-operated projects reported under Environmental Stewardship in OMBIL was useful for cross-checking the consistency of reports where ANS occurrence overlapped with invasive species occurrence. For those Districts that reported in OMBIL, survey results matched OMBIL reports quite well, thereby increasing confidence that both surveys and OMBIL reports are accurate. Exceptions to this observation - those cases where the surveys and OMBIL did not agreewere generally associated with ANS that are not considered invasive, such as native game fish and algae that have been introduced or spread beyond historical ranges in the United States. OMBIL is a potentially excellent resource for routine tracking of information of the kind sought in the surveys, including occurrence and management expenditures on all 
nuisance species at all Corps-operated projects, not just those ANS presently defined as invasive species affecting environmental stewardship. One other problem encountered with OMBIL when this study was conducted was determining if projects that have not entered information on ANS costs did not have any actual costs or had simply failed to enter information (in other words, blanks may not necessarily be equivalent to no impact).

\section{Extent of ANS impacts at Corps projects}

There appears to be no way in which ANS impacts and their management can be measured in the same terms and summed across a program of interest. OMBIL attempts measurement of impact from invasive species by reporting not only the presence of ANS, but the area colonized or otherwise affected. Measuring an occupied area works reasonably well for ANS plants and may be preferable to characterizing the extent of impacts in terms of control efforts (e.g. lake drawdown, stocking of grass carp, or other whole lake treatment). Areal measurement is a crude indicator for comparisons across sites, however, because density per unit area is highly variable. This may be best demonstrated by impacts of invasive plant and animal species at multi-purpose projects where dislodged plants, fish, and Asian clams clog trash racks. The acres occupied by these species are a crude indicator of the problem. Most impacts of animal ANS cannot be very meaningfully translated into acres impacted. Reporting impacts in terms of economic cost is preferable to reporting data that are intended to indicate the expense associated with control. However, cost data do not indicate the benefits derived from the investment.

Indicators of benefits are problematic as well. In theory, benefit is best measured in monetary terms, but some environmental values may not be acceptably measured in monetary terms (e.g. National Research Council (NRC) 2005). Economic and environmental services impacted by ANS are often identified, but simply listing impact services fails to quantify the benefits gained from resource management. Depending on the ANS involved, and particular project situations, more meaningful approaches may include measures such as loss of recreational days, increased area and frequency of flooding, decreased volume flow of water at intakes, and changes in relative abundance of endangered species. While these do not estimate benefits in a common monetary measurement, they provide much more information than simply listing service impacts. More information of 
this sort could be gathered with follow-up interviews following initial input, but these quantifiable impact data are typically scarce.

The number of environmental impacts reported in the survey of District projects was only exceeded by the number of reported recreational impacts. Environmental impacts as defined in Corps policy, however, are not to be reported in economic metrics (dollars) because the methods remain too controversial. It would be of some help if a single metric for environmental benefits could be used. But the metrics used for quantifying the environmental benefits of management actions, including ANS management, remain problematic (see, for example, Stakhiv et al. 2003). Using acres degraded as a metric is complicated by the same problems discussed above, which basically go to variation in density and other quality measures.

It is somewhat surprising that little is being spent by the Corps on animal ANS due to recent USACE involvement with barrier and trap construction in the Great Lakes region. While nearly half of Corps projects were reported to be primarily impacted by animal ANS, none incurred Corps management costs. Impacts to hydropower plants from clogging of water intakes by dead shad and encrustations of Asiatic clams appeared to be incidental compared to impacts from clogging by dead aquatic plants. Much of the reported activity by the USACE on the Great Lakes is project construction completed for another Federal agency (Great Lakes Fishery Commission) and not a cost charged to USACE operations. State agencies often get involved in reservoirs and waterways when fish impacts occur. In the case of nuisance clams, private parties that suffered the impacts of animal ANS are typically the entities that fund management efforts. While zebra mussels are capable of being a nuisance at Corps locks (O'Neill 1997), none of the locks included in this study were impacted by this species, even though zebra mussels now are known to occur widely in the Ohio River system.

The GAO (2000) reported that, for seven sampled states, expenditures for fish and invertebrate ANS ranged from \$1.8 million to \$127.6 million, with Florida having the highest expenditures. Florida expenditures on animal ANS dwarfed the $\$ 25$ million the state spent on aquatic plant control (Florida Department of Environmental Protection 2003). In the Great Lakes, lamprey and other fish management costs are covered primarily 
through the budget of the Great Lakes Fishery Commission (about $\$ 13$ million per year for lamprey management in recent years).

The cost of zebra mussel management is borne primarily by the consumers of services provided by private power companies and public water utilities that need to manage clogging of water intakes. Power plant management costs for ANS alone have been estimated to be about $\$ 60$ million per year (GAO 2002, Lovell and Stone 2005). Additional costs are incurred by recreational and commercial boat owners, and other owners of bio-fouled facilities and equipment. The total damage costs have been estimated to be about $\$ 500$ million per year.

The geographic distribution of management costs at Corps projects follows the geographic distribution of aquatic plant biomass and grouth, which is especially extensive in the southern states and, to lesser extent, in the far western states. In both regions, moderate winter temperatures and minimum ice formation favor dense growths of vascular aquatic plants. Aquatic plant impacts probably peak in Florida, based on studies of management expenditures among states (e.g., GAO 2000). The Florida Department of Environmental Protection (2003) estimated that non-native plant ANS had invaded 96\% (1,260,000 acres) of public lakes and waters. Throughout the geographic area of the three Corps Divisions sampled in the project survey, about $10 \%$ of the waters had been impacted by aquatic plants. The percentage nearly triples in SAD alone, but does not nearly approach the 96\% noted in Florida. As expected, Corps expenditures for ANS management are highest in the Southeast (with the largest expenditures in Florida), followed by the West.

The primary exceptions to the prevalence of aquatic plants in incurring management costs at Corps projects were those costs incurred by algae in two impoundments in the Northwest (i.e. NWD). Though widespread across the United States, eutrophied waters that promote the establishment of algal nuisance species are especially common in the Midwest (e.g. Omernik 1977) where LRD operates, yet algae were not reported to be a nuisance in that Division.

\section{Management efficiency at Corps projects}

Corps management has not always had a reputation for cost efficiency. Comparing management costs per unit effort reported at Corps projects to other efforts reported in the literature is complicated by the diversity of 
ways in which effort is measured. The cost of managing aquatic plants is most consistently documented. Those costs varied substantially among Corps projects surveyed in this study, but information about types of treatments used, effort expended, or cost per unit effort was not requested or received. Effort expended on the more commonly used treatments, herbicides and mechanical harvesters, is typically reported in acres (rather than time). The reported costs for these activities commonly range from less than $\$ 100$ per acre to over $\$ 2,000$ per acre in the literature.

From the limited information available at this time, Corps expenditures per acre appear to fit well within this range. A single estimate of $\$ 1,200 /$ acre/ year spent on plant control, near the median cost, was volunteered by personnel at one project surveyed in this study. Reports of plant management costs incurred under project funding reported in Corps Annual Reports (U.S. Department of the Army 2004, 2005) indicate per acre costs closer to the low end than the high end of the cost range reported in the literature. These Corps projects are typically large treatments of several thousand acres and may benefit from "economy of scale." The Corps also has been deeply involved in development of less expensive forms of treatment-mostly through use of insect, fish, and other biological controls - at its Engineer Research and Development Center. Plant species, location, and control needs influence costs. In addition, the number of treatments required often varies between fewer than once a year to several times per year, so costs per acre of treatment may not include all costs required over time. Because many of the cost components are conditional, the calculation of average costs to estimate total costs from acreage treated or total acres from the costs reported is reliable only within large confidence intervals.

The literature revealed that ANS impact management costs, when reported, did not always identify all sources of cost including labor, equipment cost and maintenance, administration, and underlying research and development costs. In general, the comparative costs of ANS management are not well developed (Rockwell 2003). Government agencies do not always consider costs incurred by the private sector in their estimates of "total" costs. Similarly, in this study of Corps management costs, it is not clear that all control costs that should be identified as ANS management costs are reflected in survey estimates. Based on the ANS literature, the estimates of ANS management costs gleaned from the Corps project survey are more likely to underestimate than overestimate ANS management costs. 


\section{Project maintenance cost devoted to ANS management}

A substantial fraction of the ANS management spending reported as operations costs most likely derived from project funding for aquatic plant control and reported as such in Civil Works Annual Reports (e.g., U.S. Department of the Army 2004, 2005). The Rivers and Harbors Act of 1965 provided for the control of water hyacinth, alligator weed, Eurasian watermilfoil, and other "noxious" plant growths in navigable and connecting waters in the combined interest of navigation, flood control, drainage, agriculture, fish and wildlife conservation, public health, and related purposes. Funds allocated through this act probably account for over three fourths of the reported Corps expenditures. Nearly \$58 million has been budgeted under this act for ANS management at the St. J ohns River and Okeechobee Waterway over the past several decades.

This source of funds was almost certainly used for ANS management at the two SAJ projects sampled in this study. A substantially lower amount has been budgeted in Mobile District (over $\$ 1,000,000$ ) for removal of water hyacinths and other aquatic plants. Cross-checking with the Civil Works Annual Report for FY 2004, once it is published, will confirm the extent to which this source of funds contributes to ANS management budgets across the Corps. About \$5 million from this fund was spent nationally on all projects in FY 2003 (U. S. Department of the Army 2004). The GAO (2000) indicated that several million dollars per year were spent by the Corps on aquatic plant management.

\section{Estimated benefits from ANS management}

Using somewhat dated data from studies done by the Corps in Florida, Rockwell (2003) estimated that the ratio of ANS management benefits to costs in Florida waters was at least 10 to 1 and based almost entirely on aquatic plant management. Because about two thirds of the estimated ANS control expenditure at Corps-operated projects was on aquatic plant management in Florida, and a high fraction of freshwater projects was sampled, an approximate minimum estimate of potential management benefit from ANS management can be made for Florida. This amounts to at least \$35 million per year assuming the conditions described by Rockwell (2003) hold. Extrapolation of this estimate to all projects in the three Divisions sampled generates an estimate of management benefits of about \$50 million per year. These estimates do not include non-monetary 
environmental benefits that may also be substantial, but are poorly estimated and documented.

\section{Further study/monitoring}

It is clear from the results of this study that a framework for systematically estimating economic and environmental benefits has yet to be developed either within or outside the Corps. Estimating environmental and economic impacts and the costs and benefits of ANS management more accurately and inclusively at Corps projects is not a trivial exercise. Monitoring management costs is easier to achieve conceptually, but even management costs are often under-reported. Present plans to incorporate management cost reporting in OMBIL in the near future ${ }^{1}$ are on the right track, especially if they eventually include all projects and all ANS, whether or not invasive. Completion of a project survey for the remaining five Divisions would serve in the interim to complete a national estimate of expenditure, and would provide a means of evaluating the accuracy of OMBIL reporting of ANS impacts.

Benefits estimation is conceptually more complicated and more expensive than estimating costs. Recreational service, the most frequent "business line" impacted at study projects, illustrates this point well. Recreational use at any one project is contingent on the distribution of the users whose largest cost is typically their travel cost. Rational users of recreational resources will seek the least costs for the specific attributes they desire at a recreational site. Therefore, all sites that might serve as an alternative to Corps project sites need to be considered in the analysis, not just Corps sites. An effective framework for estimating ANS management benefits would require a more regional and system-based approach than the Corps, or anyone else, has historically applied.

Estimating benefits of ANS control within the environmental program is perhaps the most complicated case, because no clear protocol has been accepted for assessing environmental benefits as perceived by the Corps, and because ANS impacts on environmental benefits are only rudimentarily understood. Impacts are often assumed to have occurred simply because ANS can change the attributes of an ecosystem. But change alone is not a dependable indicator of environmental damage. Even the

\footnotetext{
1 Personal Communication. 2010. R. Scott Jackson, Research Biologist, U.S. Army Engineer Research and Development Center, Vicksburg, MS.
} 
most specific remarks about ANS impacts on endangered species are rarely backed up with quantitative data, although this situation is slowly improving. Making progress in developing acceptable, standard protocols for assessing environmental benefits is important.

A comprehensive study designed to estimate economic benefit of ANS management should also consider impacts within the environmental program. However, developing a framework and a plan for such a study, understanding ANS impacts on the environmental program, will be a major endeavor. Any such Corps study would be best advised to start small and expand or conclude as results indicate. Large complicated settings would not be the best place to start such research. Recent efforts led by the Environmental Protection Agency are investigating possibilities for approaching invasive species management, including cost and benefit estimation, in a more systematic and agency-integrated way. This effort should be monitored by the Corps to assess its progress and possible benefits from Corps involvement. 


\section{Conclusions}

The following conclusions resulted from the study summarized in this report:

1. Aquatic nuisance species in freshwaters of the United States impose environmental and economic impacts significant enough to warrant substantial management costs, especially for management of vascular aquatic plants and zebra mussels.

2. Estimating national environmental and economic costs of ANS occurrence and benefits gained from ANS management have not been approached systematically and have been only crudely estimated for select ANS groups in select regions.

3. For those few species and locations where the most careful analyses have been completed, especially in Florida, the ratio of ANS management benefits to management costs is quite high—often over 10:1.

4. A significant fraction of estimated management costs is spent on vascular aquatic plant management, estimated in one study at about \$155 million annually over the United States. National management costs for animal and microbial ANS management are not as well documented, but probably are at least as much.

5. Much of the cost of management is borne by state governments and private companies and individuals. Federal agencies spent at least $\$ 20$ million per year in recent years acconding to GAO (2000), but that may be a conservative estimate.

6. Based on the results of the project survey conducted for this study, species known generally as freshwater aquatic nuisances occur at one in five Corps-operated projects, and management costs are reported for about one in ten Corps-operated projects. 
7. Comparison of study results to OMBIL survey results of invasive species occurrence at Corps projects indicated consistent reporting in both surveys. The results deviated mostly for native ANS species that are not normally considered invasive species.

8. The most frequently indicated service impact was related to recreation at Corps-operated projects, and, less frequently, to environmental services. Degradation of service in support of navigation, flood damage reduction, and water supply were less commonly indicated.

9. An average of $\$ 320,423$ was spent per project reporting an expenditure in FY 2004, but expenditures varied widely from $\$ 2,000$ to $\$ 2,300,000$.

10. The estimated total Corps expenditures for ANS management at Corps projects in the three surveyed Divisions were about $\$ 5.1$ million for FY 2004.

11. A large fraction of the Corps ANS management cost in the three surveyed Divisions studied was for large aquatic plant management, most of which was spent in SAD.

12. Two thirds of the funds estimated to have been spent by the Corps on ANS management in FY2004 were authorized for aquatic plant control under the Rivers and Harbors Act of 1965; the remaining expenditures, about \$1.6 million, came from the Operations and Management budget.

13. Based on limited information in the literature and the survey, the Corps spends less than average per acre on aquatic plant management, which may be a consequence of "economy of scale" associated with the Corps' large aquatic plant control projects.

14. The estimated economic benefit-to-cost ratio for ANS management by the Corps in Florida was at least 10:1, which amounted to at least \$35 million in benefits in FY2004. Based on ratios of regional activity, economic benefits were estimated to be approximately $\$ 50$ million across projects in all three surveyed Divisions.

15. Although environmental changes and damages are expected or assumed to occur as a consequence of ANSinvasions or rapid expansion, the environmental benefits from all ANS management are largely unknown. 
16. The three Divisions sampled are not representative of the remaining five Divisions, and extrapolation of survey results to any estimate of the total amount spent nationally at Corps-operated projects on freshwater ANS, or the nature of the services most impacted, would be unwarranted.

17. Plans to include management cost surveys in OMBIL are on the right track, especially if all Corps-operated projects and all important nuisance species are included. Completing project surveys for all eight Corps Divisions would provide a program-wide estimate of ANS occurrence and management costs that could be compared to OMBIL reporting to assess the consistency of results.

18. Confident estimation of management benefits requires a more systematic and comprehensive approach that accommodates interactions among natural processes and all human impacts, both accidental and intended, at appropriate regional scales. Establishing a framework for such analyses requires substantial research investment. Starting with a small case study makes the most sense.

19. Collaboration with other agencies in pursuit of improved estimation of invasive nuisance species is a possibility that is presently emerging in an EPA-led endeavor, which should to be monitored for its potential. 


\section{References}

Bailey, R. M., and C. R. Robins. 1991. Common and scientific names of fishes from the United States and Canada. Fifth Edition. Special Publication 30. Bethesda, MD: American Fisheries Society.

Brown, K. M. 2001. Mollusca: Gastropoda. In Ecology and classification of North American freshwater invertebrates, e.d. J.H. Thorp and A.P. Covich, 297-330. New York: Academic Press, Inc.

Cole R. A. 2005. Freshwater aquatic nuisance species impacts and management costs and benefits at federal water resources projects. ERDC/ TN ANSRP-06-3. Vicksburg, MS: U.S. Army Engineer Research and Development Center.

Fassett, N. C., and E. C. Ogden. 2006. A manual of aquatic plants. Second Edition. Madison, WI: University of Wisconsin Press.

Florida Department of Environmental Protection. 2003. Status of aquatic plant maintenance program in Florida public waters. Annual Report Fiscal 20012003 Year. Tallahassee, FL: Florida Department of Environmental Protection, Bureau of Invasive Plant Management (BIPM).

Fuller, P. L., L. G. Nico, and J . D. Williams. 1999. Nondindigenous fishes introduced into inland waters of the United States. Special Publication 27. Bethesda, MD: American Fisheries Society.

Glasner, A., and L. McKee. 2002. Pathogen occurrence and analysis in relation to water quality attainment in San Francisco Bay area watersheds. California: San Francisco Estuary Institute.

Glassner-Schwayder, K. 2000. Briefing paper: Great Lakes nonindigenous invasive species. Ann Arbor, MI: Great Lakes Commission, Resource Management and Environmental Quality Program.

Government Accounting Office (GAO). 2000. Federal and selected state funding to address harmful, nonnatives species. Report Number GAO/ RCED-00-219. Washington, DC: United States General Accounting Office.

Government Accounting Office (GAO). 2002. Invasive species: Clearer focus and greater commitment needed to effectively manage the problem. Report Number GAO03-1. Washington, DC: United States General Accounting Office.

Heinrich, J. W., K. M. Mullet, M. J . Hansen, J . V. Adams, G. T. Klar, D. A. J ohnson, G. C. Christie, and R. T. Young. 2003. Sea lamprey abundance and management in Lake Superior, 1957 to 1999. J ournal of Great Lakes Research 29:566-583.

J enkins, P. 2001. Economic impacts of aquatic nuisance species in the Great Lakes. Ontario, Canada: Phil T. J enkins \& Associates in Association with Agritrans Inc. 
Leung, B., D. M. Lodge, D. Finnoff, J. F. Shogren, M. A. Lewis, and G. Lamberti. 2002. An ounce of prevention or a pound of cure: Bioeconomic risk analysis of invasive species. In Proceedings of the Royal Society of London, Series B: Biological Sciences, 269:2407-2413.

Lovell, S. J ., and S. F. Stone. 2005. The economic impacts of aquatic invasive species: A review of the literature. Working Paper Series \#05-02, National Center for Environmental Economics. Washington, DC: U. S. Environmental Protection Agency.

MacIsaac, H., S. A. Bailey, R. Colautti, C. D. van Overdijk, and K. Amundsen. 2002. Economic impacts of invasive nonindigenous species in Canada: A case study approach. Great Lakes Institute. Ontario, Canada: University of Windsor.

Miller, A. C. 1988. Construction of a shallow-water gravel bar habitat using dredge material. EEDP-07-4. Vicksburg, MS: U.S. Army Engineer Waterways Experiment Station.

National Research Council (NRC). 2005. Valuing ecosystem services: Toward better environmental decision making. Washington, DC: National Academy Press.

Office of Technology Assessment (OTA). 1993. Harmful non-indigenous species in the United States. OTA-F-565, Washington, DC: U.S. Government Printing Office.

O'Leary, D. R., A. A. Marfin, S. P. Montgomery, A. M. Kipp, J . A. Lehman, B. J . Biggerstaff, V. L. Elko, P. D. Collins, J . E. J ones, and G. L. Campbell. 2004. The epidemic of West Nile virus in the United States, 2002. Vector-Borne and Zoonotic Diseases 4: 61-70.

Omernik, J . M. 1977. Non-point source-stream nutrient level relationships: A nationwide study. EPA600/-3-77-105. Washington, DC: U. S. Environmental Protection Agency.

O'Neill, C. R. 1997. Economic impact of zebra mussels - results of the 1995 National Zebra Mussel Information Clearinghouse Study. Great Lakes Research Review 3: 3542.

Perrings, C., M. Williamson, and S. Dalmazzone, eds. 2000. The economics of biological invasions. Northampton, MA: Edward Elgar Publishing, Inc.

Pimentel, D., L. Lach, R. Zuniga, and D. Morrison 2000. Environmental and economic costs of nonindigenous species in the United States. BioScience 50: 53-65.

Pimentel, D., R. Zuniga, and D. Morrison. 2005. Update on the environmental and economic costs associated with alien-invasive species in the United States. Ecological Economics 52:273-288.

Rabinovici, S. J . M., R.L. Bernknopf, A. M. Wein, D. L. Coursey, and R. L. Whitman. 2004. Economic and health risk trade-off of swim closures at a Lake Michigan beach. Environmental Science and Technology 38: 2737-2745.

RNT Consulting, Inc. 2002. Environmental and economic costs of alien invasive species in Canada. Ontario, Canada. 
Rockwell, W. H. 2003. Summary of a survey of the literature on the economic impact of aquatic weeds. Marietta, GA: Aquatic Ecosystem Restoration Foundation.

Stakhiv, E., R. Cole, L. Martin, and P. Scodari. 2003. Improvements in environmental benefits analysis. IWR Report 03-PS-3. Alexandria, VA: U.S. Army Corps of Engineers Institute for Water Resources.

U.S. Department of the Army. 2004. Annual report of the Secretary of the Army on Civil Works Activities (1 October 2002-30 September 2003). Washington, DC: Office of the Assistant Secretary of Civil Works.

U.S. Department of the Army. 2005. Annual report of the Secretary of the Army on Civil Works Activities (1October 2003-30 September 2004). Washington, DC: Office of the Assistant Secretary of Civil Works.

Wilcove, D. S., D. Rothstein, J . Bubow, A. Phillips and D. Losos. 1998. Quantifying threats to imperiled species in the United States. BioScience 48:607-615.

Zohrabian, A., M. I. Meltzer, R. Ratard, K. Billah, N. A. Molinari, K. Roy, R. D. Scott, and L. R. Petersen. 2004. West Nile virus economic impact, Louisiana, 2002. Emerging Infectious Diseases 10:1736-1744. 


\section{Appendix A: Survey Instrument}

Dear (Identified Party):

At the request of Corps Headquarters, the Institute for Water Resources (IWR) is cooperating with the Environmental Research and Development Center (ERDC) to evaluate the program benefits and costs associated with managing impacts from aquatic nuisance species (ANS) at operating Corps projects. As part of that evaluation we are conducting a brief survey of ANS problems existing at operating projects selected at random.

You have been identified as knowledgeable about the Project, which has been drawn to determine what ANS impacts occurred there, if any, during FY 2004 and how much was spent in FY 2004 to treat those impacts.

Did any impacts occur at the project site in FY 2004 from:

\section{$\underline{\text { Yes }} \underline{\text { No }}$}

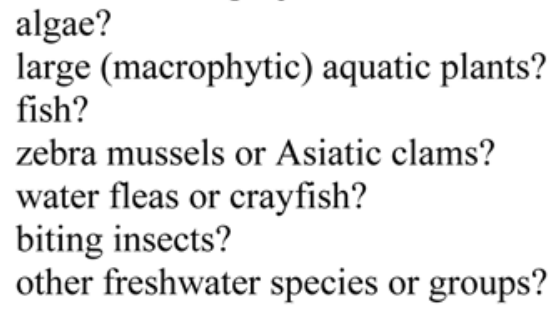

If your answers above were in all instances no, please stop here and forward the survey to Monica.A.Franklin@iwr01.usace.army.mil

For impacts known to occur at this project site, please briefly identify for each impact in FY 2004, the specific nature of the impact (e.g., interferes with swimming and boating).

Briefly, identify the ANS or ANS groups involved (e.g., Asian milfoil; leeches)

Briefly, what was done in FY 2004, if anything, to treat for the impact: (e.g., nothing; the aquatic plants were mechanically removed; snails were poisoned to stop swimmer's itch)

Were operations funds spent on ANS control/impacts at this project in FY 2004? 
What was the total operations expense for ANS control/impacts at this project site in FY $2004 ? \$$ and all projects in the District? \$

What was the requested operations budget for ANS treatment at this project site for FY $2005 ? \$$ and all projects in the District?\$

If you cannot answer some of these questions, please identify here who should be contacted to obtain the missing information:

End of Survey. Thank you. Please forward to Monica.A.Franklin@iwr01.usace.army.mil 


\section{Appendix B: Surveyed Projects}

\begin{tabular}{|c|c|c|c|c|c|c|c|c|c|}
\hline District & Project Name & $\begin{array}{l}\text { FY } 2004 \\
\text { Expense }\end{array}$ & Algae & $\begin{array}{l}\text { Large } \\
\text { Aquatic } \\
\text { Plants }\end{array}$ & Fish & Clams & $\begin{array}{l}\text { Water } \\
\text { Fleas or } \\
\text { Crayfish }\end{array}$ & Other & $\begin{array}{l}\text { ANS } \\
\text { Impact } \\
(\mathrm{Y} / \mathrm{N})\end{array}$ \\
\hline \multicolumn{10}{|c|}{ SOUTH ATLANTIC DIVISION } \\
\hline SAC & Santee River, SC & $\$ 0$ & No & No & No & No & No & No & No \\
\hline SAJ & Four River Basin, FL & $\$ 0$ & No & No & No & No & No & No & No \\
\hline SAJ & Okeechobee Waterway, FL & $\$ 1,200,000$ & Yes & Yes & Yes & No & No & No & Yes \\
\hline SAJ & St. Johns River, FL & $\$ 2,300,000$ & No & Yes & No & No & No & No & Yes \\
\hline SAM & $\begin{array}{l}\text { Black Warrior and } \\
\text { Tombigbee Rivers, AL }\end{array}$ & $\$ 60,000$ & No & Yes & No & No & No & No & Yes \\
\hline SAM & $\begin{array}{l}\text { Buford Dam \& Lake Sidney } \\
\text { Lanier, GA }\end{array}$ & $\$ 0$ & No & No & No & No & No & No & No \\
\hline SAM & $\begin{array}{l}\text { East Fork Tombigbee River, } \\
\text { MS }\end{array}$ & $\$ 0$ & No & No & No & Yes & No & No & Yes \\
\hline SAM & $\begin{array}{l}\text { Robert F. Henry Lock \& } \\
\text { Dam }\end{array}$ & $\$ 0$ & No & No & No & No & No & No & No \\
\hline SAM & $\begin{array}{l}\text { Walter F. George Lock and } \\
\text { Dam }\end{array}$ & $\$ 450,000$ & No & Yes & No & No & No & No & Yes \\
\hline SAM & $\begin{array}{l}\text { West Point Dam \& Lake, } \\
\text { GA/AL }\end{array}$ & $\$ 0$ & No & No & No & No & No & No & No \\
\hline SAS & Hartwell Lake \& Dam, GA & $\$ 0$ & No & No & No & No & No & No & No \\
\hline SAS & $\begin{array}{l}\text { J. Strom Thurmond Lake \& } \\
\text { Dam, GA/SC }\end{array}$ & $\$ 18,000$ & No & Yes & No & No & No & No & Yes \\
\hline SAW & $\begin{array}{l}\text { Cape Fear River above } \\
\text { Wilmington, NC }\end{array}$ & $\$ 0$ & No & No & No & No & No & No & No \\
\hline SAW & Falls Lake, NC & $\$ 2,000$ & Yes & Yes & No & No & No & No & Yes \\
\hline SAW & John H. Kerr Lake, VA/NC & $\$ 0$ & No & No & No & No & No & No & No \\
\hline SAW & Philpott Lake, VA & $\$ 0$ & No & No & No & No & No & No & No \\
\hline \multicolumn{10}{|c|}{ NORTHWESTERN DIVISION } \\
\hline NWK & Harlan County Lake, NE & $\$ 0$ & No & No & No & No & No & No & No \\
\hline NWK & $\begin{array}{l}\text { Harry S. Truman Dam \& } \\
\text { Reservoir, MO }\end{array}$ & $\$ 0$ & No & No & No & No & No & No & No \\
\hline NWK & Hillsdale Lake, KS & $\$ 0$ & No & No & No & No & No & No & No \\
\hline NWK & Melvern Lake, KS & $\$ 0$ & No & No & No & No & No & No & No \\
\hline NWK & Milford Lake, KS & $\$ 0$ & No & No & No & No & No & No & No \\
\hline
\end{tabular}




\begin{tabular}{|c|c|c|c|c|c|c|c|c|c|}
\hline District & Project Name & $\begin{array}{l}\text { FY } 2004 \\
\text { Expense }\end{array}$ & Algae & $\begin{array}{l}\text { Large } \\
\text { Aquatic } \\
\text { Plants }\end{array}$ & Fish & Clams & $\begin{array}{l}\text { Water } \\
\text { Fleas or } \\
\text { Crayfish }\end{array}$ & Other & $\begin{array}{l}\text { ANS } \\
\text { Impact } \\
(\mathrm{Y} / \mathrm{N})\end{array}$ \\
\hline NWK & Pomme De Terre Lake, MO & $\$ 0$ & No & No & No & No & No & No & No \\
\hline NWK & Rathbun Lake, IA & $\$ 0$ & Yes & No & No & No & No & No & Yes \\
\hline NWK & Smithville Lake, MO & $\$ 0$ & No & No & No & No & No & No & No \\
\hline NWK & Tuttle Creek Lake, KS & $\$ 0$ & No & No & No & No & No & No & No \\
\hline NWO & Bowman-Haley Lake, ND & $\$ 0$ & No & No & No & No & No & No & No \\
\hline NWO & Chatfield Lake, CO & $\$ 0$ & Yes & No & No & No & No & No & Yes \\
\hline NWO & Lake Oahe, ND/SD & $\$ 0$ & No & Yes & No & No & No & No & Yes \\
\hline NWO & $\begin{array}{l}\text { Papillion Cree \& Tributaries } \\
\text { Lakes }\end{array}$ & $\$ 0$ & No & No & Yes & No & No & No & Yes \\
\hline NWP & Bonneville Dam, OR/WA & $\$ 25,000$ & No & Yes & Yes & Yes & No & No & Yes \\
\hline NWP & $\begin{array}{l}\text { Columbia River at Baker } \\
\text { Bay, OR }\end{array}$ & $\$ 0$ & No & No & No & No & No & No & No \\
\hline NWP & $\begin{array}{l}\text { Columbia River b/w } \\
\text { Chinook \& Sand Island, OR }\end{array}$ & $\$ 0$ & No & No & No & No & No & No & No \\
\hline NWP & Hills Creek Dam, OR & $\$ 0$ & Yes & No & No & No & No & No & No \\
\hline NWP & $\begin{array}{l}\text { John Day Lock and Dam, } \\
\text { OR }\end{array}$ & $\$ 30,000$ & No & Yes & Yes & Yes & No & No & Yes \\
\hline NWP & Lost Creek Dam, OR & $\$ 0$ & Yes & No & No & No & No & No & Yes \\
\hline NWP & Willow Creek Lake, OR & $\$ 50,000$ & Yes & No & No & No & No & No & Yes \\
\hline NWS & Albeni Falls Dam, ID & $\$ 8,000$ & No & Yes & No & No & No & No & Yes \\
\hline NWS & Chief Joseph Dam, WA & $\$ 0$ & No & Yes & No & No & No & No & Yes \\
\hline NWS & Howard Hanson Dam, WA & $\$ 0$ & No & No & Yes & No & No & No & Yes \\
\hline NWS & Mud Mountain Dam, WA & $\$ 0$ & No & No & No & No & No & No & No \\
\hline NWW & $\begin{array}{l}\text { Little Goose Lock \& Dam, } \\
\text { ID }\end{array}$ & $\$ 2,500$ & No & Yes & Yes & No & No & No & Yes \\
\hline NWW & Lucky Peak, ID & $\$ 0$ & No & No & No & No & No & No & No \\
\hline NWW & $\begin{array}{l}\text { McNary Lock \& Dam, Lake } \\
\text { Wallula, OR/WA }\end{array}$ & $\$ 15,000$ & Yes & Yes & Yes & No & No & No & Yes \\
\hline \multicolumn{10}{|c|}{ GREAT LAKES \& OHIO RIVER DIVISION } \\
\hline LRB & Ashtabula Harbor, $\mathrm{OH}$ & $\$ 0$ & No & No & No & No & No & No & No \\
\hline LRB & Geneva on the Lake, $\mathrm{OH}$ & $\$ 0$ & No & No & No & No & No & No & No \\
\hline LRB & Olcott Harbor, NY & $\$ 0$ & No & No & No & No & No & No & No \\
\hline LRB & Oswego Harbor, NY & $\$ 0$ & No & No & No & No & No & No & No \\
\hline LRB & Sackets Harbor, NY & $\$ 0$ & No & No & No & No & No & No & No \\
\hline
\end{tabular}




\begin{tabular}{|c|c|c|c|c|c|c|c|c|c|}
\hline District & Project Name & $\begin{array}{l}\text { FY } 2004 \\
\text { Expense }\end{array}$ & Algae & $\begin{array}{l}\text { Large } \\
\text { Aquatic } \\
\text { Plants }\end{array}$ & Fish & Clams & $\begin{array}{l}\text { Water } \\
\text { Fleas or } \\
\text { Crayfish }\end{array}$ & Other & $\begin{array}{l}\text { ANS } \\
\text { Impact } \\
(\mathrm{Y} / \mathrm{N})\end{array}$ \\
\hline LRB & Sandusky Harbor, $\mathrm{OH}$ & $\$ 0$ & No & No & No & No & No & No & No \\
\hline LRB & West Harbor, $\mathrm{OH}$ & $\$ 0$ & No & No & No & No & No & No & No \\
\hline LRC & $\begin{array}{l}\text { Burns Waterway Small Boat } \\
\text { Harbor, IN }\end{array}$ & $\$ 0$ & No & No & No & No & No & No & No \\
\hline LRC & Chicago River Harbor, IL & $\$ 0$ & No & No & No & No & No & No & No \\
\hline LRC & Michigan City Harbor, IN & $\$ 0$ & No & No & No & No & No & No & No \\
\hline LRC & Waukegan Harbor, IL & $\$ 0$ & No & No & No & No & No & No & No \\
\hline LRE & AuSable Harbor, MI & $\$ 0$ & No & No & No & No & No & No & No \\
\hline LRE & Chippewa Harbor, MI & $\$ 0$ & No & No & No & No & No & No & No \\
\hline LRE & Clinton River, MI & $\$ 0$ & No & No & No & No & No & No & No \\
\hline LRE & Cornucopia Harbor, WI & $\$ 0$ & No & No & No & No & No & No & No \\
\hline LRE & Detour Harbor, MI & $\$ 0$ & No & No & No & No & No & No & No \\
\hline LRE & Eagle Harbor, MI & $\$ 0$ & No & No & No & No & No & No & No \\
\hline LRE & Frankfort Harbor, MI & $\$ 0$ & No & No & No & No & No & No & No \\
\hline LRE & Holland Harbor, MI & $\$ 0$ & No & No & No & No & No & No & No \\
\hline LRE & Kenosha Harbor, WI & $\$ 0$ & No & No & No & No & No & No & No \\
\hline LRE & Kewaunee Harbor, WI & $\$ 0$ & No & No & No & No & No & No & No \\
\hline LRE & La Pointe Harbor, WI & $\$ 0$ & No & No & No & No & No & No & No \\
\hline LRE & Les Cheneaux Island, MI & $\$ 0$ & No & No & No & No & No & No & No \\
\hline LRE & Mackinaw City Harbor, MI & $\$ 0$ & No & No & No & No & No & No & No \\
\hline LRE & Marquette Harbor, MI & $\$ 0$ & No & No & No & No & No & No & No \\
\hline LRE & Monroe Harbor, MI & $\$ 0$ & No & No & No & No & No & No & No \\
\hline LRE & New Buffalo Harbor, MI & $\$ 0$ & No & No & No & No & No & No & No \\
\hline LRE & Petoskey Harbor, MI & $\$ 0$ & No & No & No & No & No & No & No \\
\hline LRE & Point Lookout Harbor, MI & $\$ 0$ & No & No & No & No & No & No & No \\
\hline LRE & Sebewaing River, MI & $\$ 0$ & No & No & No & No & No & No & No \\
\hline LRE & Whitefish Point Harbor, MI & $\$ 0$ & No & No & No & No & No & No & No \\
\hline LRH & Beech Fork Lake, WV & $\$ 0$ & No & No & No & No & No & No & No \\
\hline LRH & Deer Creek Lake, $\mathrm{OH}$ & $\$ 0$ & No & No & No & No & No & No & No \\
\hline LRH & Delaware Lake, $\mathrm{OH}$ & $\$ 0$ & No & No & No & No & No & No & No \\
\hline LRH & Fishtrap Lake, KY & $\$ 0$ & No & No & No & No & No & No & No \\
\hline LRH & Grayson Lake, KY & $\$ 0$ & No & No & No & No & No & No & No \\
\hline
\end{tabular}




\begin{tabular}{|c|c|c|c|c|c|c|c|c|c|}
\hline District & Project Name & $\begin{array}{l}\text { FY } 2004 \\
\text { Expense }\end{array}$ & Algae & $\begin{array}{l}\text { Large } \\
\text { Aquatic } \\
\text { Plants }\end{array}$ & Fish & Clams & $\begin{array}{l}\text { Water } \\
\text { Fleas or } \\
\text { Crayfish }\end{array}$ & Other & $\begin{array}{l}\text { ANS } \\
\text { Impact } \\
(\mathrm{Y} / \mathrm{N})\end{array}$ \\
\hline $\mathrm{LRH}$ & $\begin{array}{l}\text { John W. Flannagan Dam } \\
\text { and Reservoir, VA }\end{array}$ & $\$ 0$ & No & No & No & No & No & No & No \\
\hline $\mathrm{LRH}$ & $\begin{array}{l}\text { North Fork of Pound River } \\
\text { Lake, VA }\end{array}$ & $\$ 0$ & No & No & No & No & No & No & No \\
\hline LRH & Paint Creek Lake, $\mathrm{OH}$ & $\$ 0$ & No & No & No & No & No & No & No \\
\hline LRH & R.D. Bailey Lake, WV & $\$ 0$ & No & No & No & No & No & No & No \\
\hline LRH & Sutton Lake, WV & $\$ 0$ & No & No & No & No & No & No & No \\
\hline LRL & Barren River Lake, KY & $\$ 0$ & No & No & No & No & No & No & No \\
\hline LRL & Buckhorn Lake, KY & $\$ 0$ & No & No & No & No & No & No & No \\
\hline LRL & Cannelton Locks \& Dam, IN & $\$ 0$ & No & No & No & No & No & No & No \\
\hline LRL & Carr Creek Lake, KY & $\$ 0$ & No & No & No & No & No & No & No \\
\hline LRL & Ceasar Creek Lake, $\mathrm{OH}$ & $\$ 0$ & No & No & No & No & No & No & No \\
\hline LRL & Cecil M. Harden Lake, IN & $\$ 0$ & No & No & No & No & No & No & No \\
\hline LRL & Green River Lake, KY & $\$ 0$ & No & No & No & No & No & No & No \\
\hline LRL & J. Edward Roush Lake, IN & $\$ 0$ & No & No & No & No & No & No & No \\
\hline LRL & $\begin{array}{l}\text { Lock \& Dam No. 2, Green } \\
\text { River, KY }\end{array}$ & $\$ 0$ & No & No & No & No & No & No & No \\
\hline LRL & $\begin{array}{l}\text { Lock \& Dam No. 52, Ohio } \\
\text { River, KY }\end{array}$ & $\$ 0$ & No & No & No & No & No & No & No \\
\hline LRL & Newburgh Locks \& Dam, IN & $\$ 0$ & No & No & No & No & No & No & No \\
\hline LRL & Nolin Lake, KY & $\$ 0$ & No & No & No & No & No & No & No \\
\hline LRL & Patoka Lake, IN & $\$ 0$ & No & No & No & No & No & No & No \\
\hline LRL & Rough River Lake, KY & $\$ 0$ & No & No & No & No & No & No & No \\
\hline LRL & Salamonie Lake, IN & $\$ 0$ & No & No & No & No & No & No & No \\
\hline LRL & Taylorsville Lake, KY & $\$ 0$ & No & No & No & No & No & No & No \\
\hline LRN & $\begin{array}{l}\text { Barkley Dam \& Lake } \\
\text { Barkley, KY }\end{array}$ & $\$ 0$ & No & No & No & No & No & No & No \\
\hline LRN & Center Hill Lake, TN & $\$ 0$ & No & No & No & No & No & No & No \\
\hline LRN & Cheatham Lock \& Dam, TN & $\$ 0$ & No & No & No & No & No & No & No \\
\hline LRN & Cumberland River, TN/KY & $\$ 0$ & No & No & No & No & No & No & No \\
\hline LRN & Dale Hollow Lake, TN & $\$ 0$ & No & No & No & No & No & No & No \\
\hline LRN & Martins Fork Dam, KY & $\$ 0$ & No & No & No & No & No & No & No \\
\hline LRN & $\begin{array}{l}\text { Middlesboro Cumberland } \\
\text { River Basin, KY }\end{array}$ & $\$ 0$ & No & No & No & No & No & No & No \\
\hline
\end{tabular}




\begin{tabular}{|c|c|c|c|c|c|c|c|c|c|}
\hline District & Project Name & $\begin{array}{l}\text { FY } 2004 \\
\text { Expense }\end{array}$ & Algae & $\begin{array}{l}\text { Large } \\
\text { Aquatic } \\
\text { Plants }\end{array}$ & Fish & Clams & $\begin{array}{l}\text { Water } \\
\text { Fleas or } \\
\text { Crayfish }\end{array}$ & Other & $\begin{array}{l}\text { ANS } \\
\text { Impact } \\
(\mathrm{Y} / \mathrm{N})\end{array}$ \\
\hline LRN & $\begin{array}{l}\text { Wolf Creek Dam, Lake } \\
\text { Cumberland, KY }\end{array}$ & $\$ 0$ & No & No & No & No & No & No & No \\
\hline LRP & Berlin Lake, $\mathrm{OH}$ & $\$ 0$ & No & No & No & No & No & No & No \\
\hline LRP & Crooked Creek Lake, PA & $\$ 0$ & No & No & No & No & No & No & No \\
\hline LRP & $\begin{array}{l}\text { Dashields Locks and Dam, } \\
\text { Ohio River, PA }\end{array}$ & $\$ 0$ & No & No & No & No & No & No & No \\
\hline LRP & $\begin{array}{l}\text { East Branch Clarion River } \\
\text { Lake, PA }\end{array}$ & $\$ 0$ & No & No & No & No & No & No & No \\
\hline LRP & $\begin{array}{l}\text { Grays Landing Lock and } \\
\text { Dam, Monongahela River, } \\
\text { PA }\end{array}$ & $\$ 0$ & No & No & No & No & No & No & No \\
\hline LRP & $\begin{array}{l}\text { Kinzua Dam and Allegheny } \\
\text { Reservoir, PA }\end{array}$ & $\$ 5,000$ & No & No & Yes & No & Yes & No & Yes \\
\hline LRP & $\begin{array}{l}\text { Lock and Dam No 7, } \\
\text { Allegheny River, PA }\end{array}$ & $\$ 0$ & No & No & No & No & No & No & No \\
\hline LRP & $\begin{array}{l}\text { Lock and Dam No. 4, } \\
\text { Monongahela River PA }\end{array}$ & $\$ 0$ & No & No & No & No & No & No & No \\
\hline LRP & Loyalhanna Lake, PA & $\$ 0$ & No & No & No & No & No & No & No \\
\hline LRP & Mahoning Creek Lake, PA & $\$ 0$ & No & No & No & No & No & No & No \\
\hline LRP & $\begin{array}{l}\text { Montgomery Locks and } \\
\text { Dam, Ohio River, PA }\end{array}$ & $\$ 0$ & No & No & No & No & No & No & No \\
\hline LRP & Mosquito Creek Lake, $\mathrm{OH}$ & $\$ 0$ & No & No & No & No & No & No & No \\
\hline LRP & Shenango River Lake, PA & $\$ 0$ & No & No & No & No & No & No & No \\
\hline LRP & $\begin{array}{l}\text { Stonewall Jackson Lake, } \\
\text { WV }\end{array}$ & $\$ 0$ & No & No & No & No & No & No & No \\
\hline LRP & Tygart Lake, WV & $\$ 0$ & No & No & No & No & No & No & No \\
\hline LRP & Union City Lake, PA & $\$ 0$ & No & No & No & No & No & No & No \\
\hline
\end{tabular}




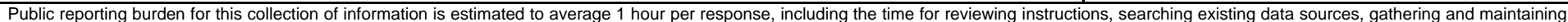

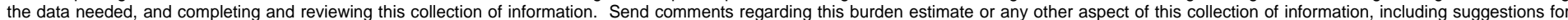

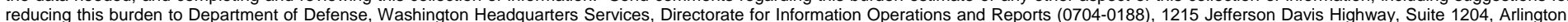

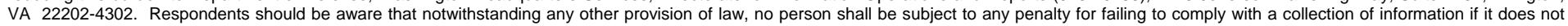
display a currently valid OMB control number. PLEASE DO NOT RETURN YOUR FORM TO THE ABOVE ADDRESS.

\begin{tabular}{l|c}
$\begin{array}{l}\text { 1. REPORT DATE (DD-MM-YYYY) } \\
\text { July } 2010\end{array}$ & $\begin{array}{c}\text { 2. REPORT TYPE } \\
\text { Final report }\end{array}$ \\
\hline
\end{tabular}

\section{TITLE AND SUBTITLE}

Incidence and Management Costs of Freshwater Aquatic Nuisance Species at Projects Operated by the U.S. Army Corps of Engineers

3. DATES COVERED (From - To)

5a. CONTRACT NUMBER

5b. GRANT NUMBER

5c. PROGRAM ELEMENT NUMBER

\section{AUTHOR(S)}

5d. PROJECT NUMBER

Richard A. Cole, Paul F. Scodari, and Monica A. Franklin

5e. TASK NUMBER

5f. WORK UNIT NUMBER

7. PERFORMING ORGANIZATION NAME(S) AND ADDRESS(ES)

8. PERFORMING ORGANIZATION REPORT NUMBER

Institute for Water Resources

U.S. Army Corps of Engineers

ERDC/EL TR-10-13

7701 Telegraph Road

Alexandria, VA 22315-3868

\section{SPONSORING / MONITORING AGENCY NAME(S) AND ADDRESS(ES)}

10. SPONSOR/MONITOR'S ACRONYM(S)

U.S. Army Engineer Research and Development Center

Environmental Laboratory

3909 Halls Ferry Road

Vicksburg, MS 39180-6199

11. SPONSOR/MONITOR'S REPORT NUMBER(S)

\section{DISTRIBUTION / AVAILABILITY STATEMENT}

Approved for public release; distribution is unlimited.

\section{SUPPLEMENTARY NOTES}

\section{ABSTRACT}

This study investigates the costs and possible benefits associated with freshwater aquatic nuisance species (ANS) at projects operated by the U.S. Army Corps of Engineers. Based on results from a random-sample survey of three Corps Divisions (LRD, NWD, and SAD), ANS occurred at $16.9 \%$ of Corps projects and ANS management costs were incurred at 10.5\% of the projects (\$4,165,500 total expenses). Most ANS occurrences were large aquatic plants, which incurred $98 \%$ of the management cost. Algae management made up most of the remaining cost. Based on a literature review, Corps expenses are a small fraction of the total ANS management expense in the United States. Florida management costs are among the best documented and are over 40 times the Corps expenditure in Florida. Corps costs per unit effort are lower than average. If the benefit-to-cost ratio found for Florida in the ANS literature generally applies, the benefits derived from Corps ANS management are about \$35 million per year in the Jacksonville District alone and \$50 million per year in the surveyed Divisions. Benefits from improved habitat for threatened native species may also be substantial, but are poorly estimated.

\section{SUBJECT TERMS}

Aquatic nuisance species

Management costs and benefits

16. SECURITY CLASSIFICATION OF:

\section{a. REPORT}

UNCLASSIFIED b. ABSTRACT UNCLASSIFIED c. THIS PAGE

UNCLASSIFIED
17. LIMITATION OF ABSTRACT
18. NUMBER OF PAGES

59 19a. NAME OF RESPONSIBLE PERSON

19b. TELEPHONE NUMBER (include area code) 